\title{
Nanotheranostic Carbon Dots as an Emerging Platform for Cancer Therapy
}

\author{
Sumiya Haque Adrita ${ }^{1}$, Khandaker Nujhat Tasnim ${ }^{1}$, Ji Hyun Ryu ${ }^{2}$ (i) and \\ Shazid Md. Sharker $1, *$ (D) \\ 1 Department of Pharmaceutical Sciences, North South University, Dhaka 1229, Bangladesh; \\ sumiyaadrita09@gmail.com (S.H.A.); nujhat.tasnim15@gmail.com (K.N.T.) \\ 2 Department of Carbon Convergence Engineering, Wonkwang University, Iksan, Jeonbuk 54538, Korea; \\ jhryu4816@wku.ac.kr \\ * Correspondence: shazid.sharker@northsouth.edu; Tel.: +88-025-566-8200 (ext. 6402) \\ Academic Editor: Seok Ki Choi \\ Received: 30 September 2020; Accepted: 13 November 2020; Published: 23 November 2020

\begin{abstract}
Cancer remains one of the most deadly diseases globally, but carbon-based nanomaterials have the potential to revolutionize cancer diagnosis and therapy. Advances in nanotechnology and a better understanding of tumor microenvironments have contributed to novel nanotargeting routes that may bring new hope to cancer patients. Several low-dimensional carbon-based nanomaterials have shown promising preclinical results; as such, low-dimensional carbon dots (CDs) and their derivatives are considered up-and-coming candidates for cancer treatment. The unique properties of carbon-based nanomaterials are high surface area to volume ratio, chemical inertness, biocompatibility, and low cytotoxicity. It makes them well suited for delivering chemotherapeutics in cancer treatment and diagnosis. Recent studies have shown that the CDs are potential applicants in biomedical sciences, both as nanocarriers and nanotransducers. This review covers the most commonly used CD nanoparticles in nanomedicines intended for the early diagnosis and therapy of cancer.
\end{abstract}

Keywords: carbon nanoparticles; CDs; bioimaging; drug delivery system; theranostic

\section{Introduction}

Low-dimensional carbon dots (CDs) are known as carbon nanodots, carbon nanoparticles, carbon quantum dots, carbogenic quantum dots, or fluorescent carbon nanoparticles (FCNs). The ideal size of these quasispherical CDs is usually less than $20 \mathrm{~nm}$ (nanometers) or even $1 \mathrm{~nm}$. The main component of CDs is carbon, so the sources for synthesis are easily obtainable. The CDs are $\mathrm{sp}^{2}$ - and $\mathrm{sp}^{3}$-type hybridized carbon, commonly known as the " $\mathrm{D}$ " (diamond) and " $\mathrm{G}$ " (graphene) band carbon. Moreover, $\mathrm{CDs}$ decorated with surface functional groups such as $-\mathrm{COOH},-\mathrm{OH},-\mathrm{CHO}$, and $-\mathrm{NH}_{2}$ are sufficiently soluble in water, which is the prerequisite for drug loading and thus a drug carrier. CDs can increase photoluminescence (PL) when polymer chains are attached to the uncovered surface, making a bioimaging probe for cancer diagnosis [1-6]. At the same time, CDs offer the development of theranostic (therapeutic and diagnostic) nanoparticles for combined cancer imaging and therapy.

The fascinating photoluminescence (PL) property of CDs can be used in different biomedical fields, especially in cancer diagnosis and therapy. Typically, the CDs show a full absorption spectrum in the ultraviolet (UV) region, owing to the extensive $\pi$-conjugated electrons in a sp $\mathrm{sp}^{2}$ carbon skeleton. Attributed to them are $\pi-\pi^{*}$ transition for the $C=C$ bonds and $n-\pi^{*}$ transition for the $C=O$ bonds or other connected groups. Additionally, CDs with different sizes, composition, structure, or surface passivation effect can change their light absorption spectrum [7-9].

The emission spectrum of CDs is excitation-dependent and ranging from UV to the visible or near-infrared (NIR) region. Therefore, they are highly promising for multicolor bioimaging applications. 
Although the mechanism of PL emission is still a controversial issue with regard to CDs, it is an essential tool for biomedical use (Figure 1). There are two proposed mechanisms: the quantum confinement effect (QCE) mechanism based on the band gap of the conjugated $\pi$-electron, and the edge effect mechanism based on the surface defect states of both $\mathrm{sp}^{3}$ and $\mathrm{sp}^{2}$ hybridized carbons. This effect increases the localization of electrons on CDs and contributes to multicolor fluorescence emissions (Figure $1 b, c)$. Furthermore, their inherent photostability and introduced surface passivation properties could amplify the fluorescent properties and empower their biological application in different ways. In the case of surface passivation, the increased densities of the $\pi$-electrons facilitate the radiative combination and the quantum confinement of electron-holes $(\mathrm{e} / \mathrm{h})$ pairs have improved the fluorescent properties of raw CDs [7,10-12].

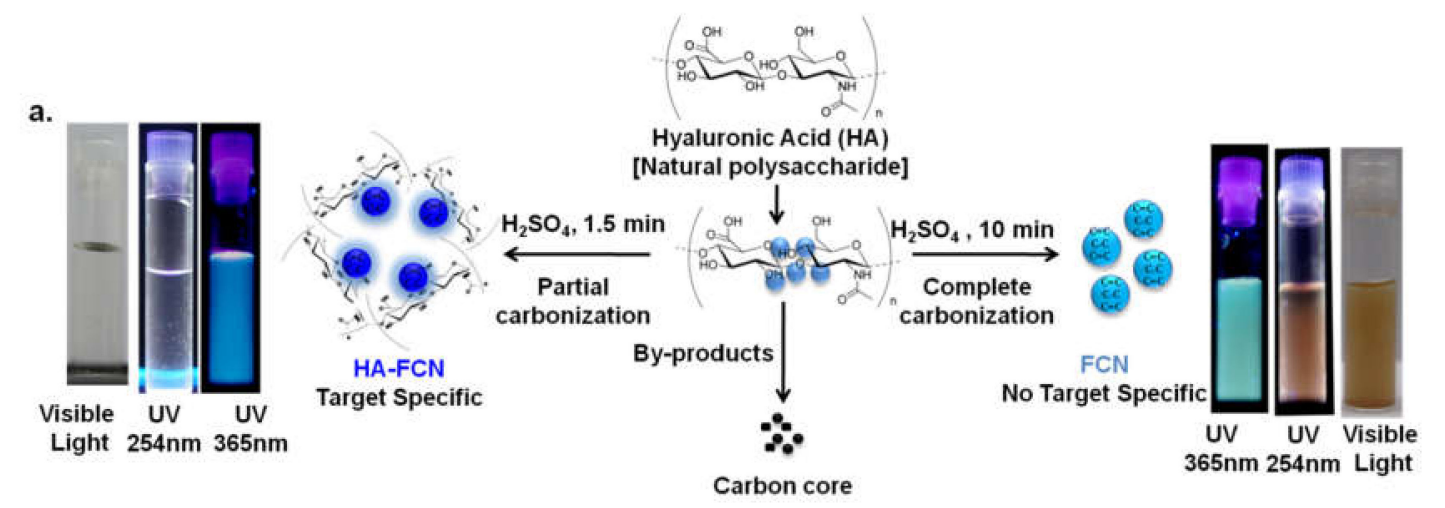

b.
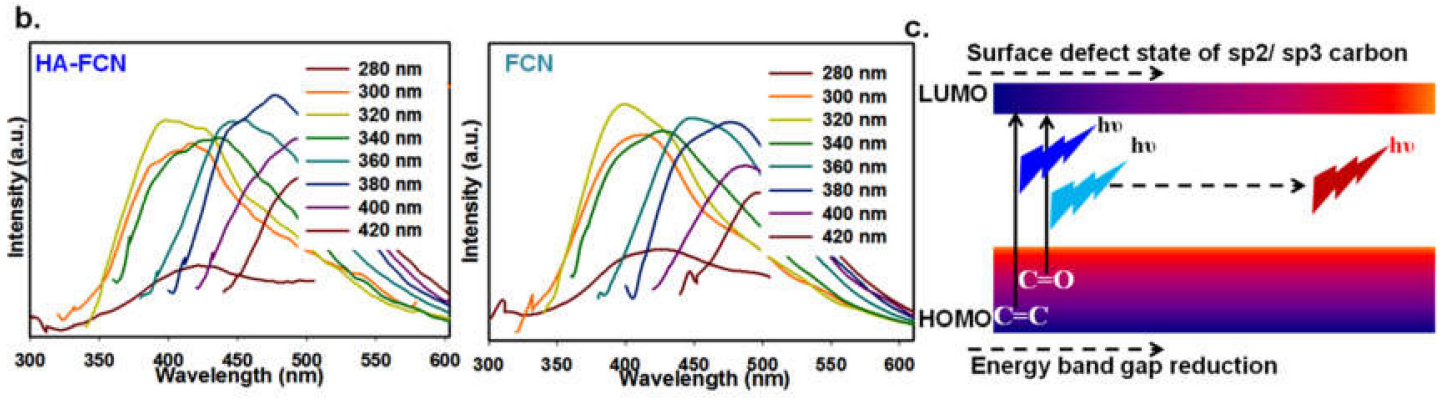

Figure 1. (a) Scheme of synthesis of carbon dots (CDs) from hyaluronic acid (HA) and illuminated photograph of aqueous solutions of HA-derived HA-FCN (hyaluronic acid-fluorescent carbon nanoparticles) and FCN under visible light, and $254 \mathrm{~nm}$ and $365 \mathrm{~nm}$ UV lamps. (b) The excitation wavelength-dependent fluorescence emission spectra of HA-FCN and FCN. (c) The graphical representation of the typical fluorescence emission mechanism of CDs. (C) The Royal Society of Chemistry [13].

FCNs (fluorescent carbon nanoparticles), a type of CDs, are considered excellent luminescence probes for bioimaging due to their unique optical properties, size tuning capacity, surface functionalization capacity, and reduced photo blinking and photobleaching characteristics. Although the surface functionalization of CDs is a complicated engineering method, the resultant fabricated and functionalized CDs can exhibit multiple functions. They can work as a unique drug carrier system and a gene delivering aid. Furthermore, the modified CDs are excellent phototherapeutic agents and sensor probes for various therapeutic and diagnostic purposes, possibly due to their maximum drug-loading capacity $[13,14]$. Numerous in vitro and in vivo studies have shown CDs have low toxicity or are nontoxic compared to other fluorescent nanomaterials. Moreover, the ease of administration of CDs via different routes, such as oral, nasal, and parenteral, makes them better and more convenient forms of drug delivery systems to deliver therapeutic substances.

Cancer therapy and diagnosis remain among the most challenging tasks throughout the world. The cancer treatments used against diseases are chemotherapy, radiation, and surgery. Each of these 
treatments has some merits and demerits, and one treatment pathway cannot address all the types of cancer. In this context, chemotherapeutic delivery and diagnosis based on nanoparticles (NPs) such as CDs could be considered to be potential candidates and have shown promising results recently. CDs can work in the nano-bio interface, where the light induces specific photochemical or photophysical reactions allowing diagnosis and chemotherapeutic delivery. They can also be used in cytotoxic cancer therapy, such as photodynamic therapy (PDT) and photothermal therapy (PTT) [7,15-20].

The competitors of CDs are quantum dots (QDs), which are semiconductors in nature and have been used as excellent fluorescent probes in biomedicine, optoelectronic devices, and biological identification. The typical QDs contain heavy metals such as Cd (cadmium) or Hg (mercury) that cause many health and environmental hazards; however, green and environmentally friendly QDs have demonstrated a wide variety of therapeutic applications [19,20]. In contrast, CDs do not carry such heavy materials, which make them safe to use, and this is a significant difference between them. The QDs have lower quantum yield and narrower size distribution than CDs. However, QDs are small in size and have a wide surface area, so multiple conjugations are possible, which might not be possible with CDs. Moreover, compared to classic organic (fluorescence) dyes, the CDs show extraordinary attributes; for instance, higher photostability, brighter fluorescence, better biocompatibility, high quantum yield, and less photobleaching. The typical organic dyes may agglomerate within the cell, or interaction with other dyes might cause quenching of those dyes and ultimately show toxicity [21-24]. Therefore, this review focuses on the recent development of CDs, emphasizing the source and methods for synthesis and their surface engineering. The review article also includes different diagnosis results, drug delivery systems (DDS), and biomedical uses for therapeutic purposes.

\section{Existing Sources and Technologies for the Synthesis of Carbon Dots (CDs)}

Until now, two different strategies, namely "top-down" and "bottom-up", have been used to synthesize carbon nanoparticles or CDs from various carbon precursors (Table 1). In the case of top-down strategies, large carbon structures are broken to form carbonaceous nanoparticles or CDs. Laser ablation, arc discharge, and electrochemical oxidation have been used in this regard. The bottom-up approach leads to several CDs from carbon sources subjected to thermal combustion, acidic oxidation, hydrothermal oxidation, and microwave methods (Figure 1a) [14]. After synthesis, both top-down and bottom-up approaches use centrifugation, dialysis, or electrophoresis to separate and purify CDs [25]. However, these processes only produce small-scale products due to low yield, complicated processes, and critical synthetic conditions. Consequently, researchers are still searching for better options to make large-scale and more effective components and methods to synthesize CDs [26].

Table 1. Source and synthesis of carbon dots (CDs).

\begin{tabular}{ccc}
\hline Source & Example & Reference \\
\hline & 1. Watermelon peel & {$[27]$} \\
2. Mango fruit & {$[28]$} \\
CDs from natural products & 3. Food caramels & {$[29]$} \\
& 4. Egg yolk & {$[30]$} \\
& 6. Orange peel & {$[31]$} \\
& 7. Tapa bispinosa peel & {$[33]$} \\
8. Banana & {$[34]$} \\
& 9. Linseed & {$[35]$} \\
10. Schizonepetae herba carbonisata & {$[36]$} \\
& 11. Milk & {$[37]$} \\
\hline
\end{tabular}


Table 1. Cont.

\begin{tabular}{|c|c|c|}
\hline Source & Example & Reference \\
\hline \multirow{7}{*}{ CDs from biomaterials } & 1. Melanin granules & [38] \\
\hline & 2. Chitosan & [39] \\
\hline & 3. Dopamine-melanin & {$[40]$} \\
\hline & 4. Polydopamine & [41] \\
\hline & 5. Folic acid & [42] \\
\hline & 6. Hair fiber & [43] \\
\hline & 7. Bovine serum albumin & {$[44]$} \\
\hline \multirow{10}{*}{ CDs from carbon precursors } & 1. Silica spheres & [45] \\
\hline & 2. Kerosene & [46] \\
\hline & 3. Carbon soot & [47] \\
\hline & 4. Graphite powders & [48] \\
\hline & 5. Candle soot & [49] \\
\hline & 6. Active carbon & [50] \\
\hline & 7. Graphite & [51] \\
\hline & 8. Silane & [52] \\
\hline & 9. Activated carbon fiber & [53] \\
\hline & 10. Frying oil & [54] \\
\hline \multirow{5}{*}{ CDs from carbohydrates } & 1. Sucrose & [55] \\
\hline & 2. Saccharide & [56] \\
\hline & 3. Glucose & {$[57]$} \\
\hline & 4. Carbohydrate & [58] \\
\hline & 5. Flour & [59] \\
\hline \multirow{15}{*}{ CDs from chemical materials } & 1. Poly-(N-isopropyl-acryl-amide) & {$[60]$} \\
\hline & 2. Poly-(dimethyl-aminoethyl-methacrylate) & [61] \\
\hline & 3. Succinic acid and tris-(2-aminoethyl)amine & [62] \\
\hline & 4. Polyacrylamide & [63] \\
\hline & 5. Lauryl-gallate & [64] \\
\hline & 6. L-ascorbic acid & {$[65]$} \\
\hline & 7. EDTA & {$[66]$} \\
\hline & 8. Pluronic ${ }^{\circledR} \mathrm{F}-127$ & [67] \\
\hline & 9. Resorcinol and formaldehyde & {$[68]$} \\
\hline & 10. Aromatic compounds & [69] \\
\hline & 11. Sodium citrate & {$[70]$} \\
\hline & 12. Polyamine & [71] \\
\hline & 13. Polystyrene & {$[72]$} \\
\hline & 14. Peroxynitrous acid & [73] \\
\hline & 15. Xylan & {$[74]$} \\
\hline
\end{tabular}

Modification and fabrication of the surface and carbogenic core of CDs are possible with various engineering methods so that the required physicochemical and optical properties can be achieved. Depending on the intended use of the CDs, the fabrication and modification method will vary and give rise to the desired properties for optimum use. Recently, various types of doped CDs have been produced by doping hetero atoms, such as boron $(B)$, fluorine $(\mathrm{F})$, nitrogen $(\mathrm{N})$, sulfur $(\mathrm{S})$, and phosphorous $(\mathrm{P})$, into the basic structure $(\mathrm{C}, \mathrm{H}$, and $\mathrm{O})$ to prepare $\mathrm{B}-/ \mathrm{F}-/ \mathrm{N}-/ \mathrm{P}-/ \mathrm{S}-$ doped $\mathrm{CDs}$ [75]. Among them, the fluorinated CDs exhibit high transfection efficiency for nucleic acid delivery. Besides, $\mathrm{N}$ - and S-codoped CDs have been found to present a unique quenching mechanism for detecting the anticancer drug methotrexate via fluorescence resonance energy transfer (FRET) between codoped CDs and the drug itself, which is highly beneficial for cancer theranostics [76].

Recent studies have revealed CDs modified for fluorescence intensity, wavelength, and lifetime showing high sensitivity and linearity depending on the temperature. This property is considered highly beneficial for various biomedical uses, such as the release of drugs at body temperature (Figure 2) [60,77-79]. In one study, multiband wavelength active carbon dots (CDs) as the sensitizers in $3 \mathrm{D}$ (three-dimensional) porous zinc oxide $(\mathrm{ZnO})$ microspheres showed superior optical and 
photoelectrical properties compared to bare $\mathrm{ZnO}$. The modified CDs can work as highly active photocatalysts in various biological processes [80,81].

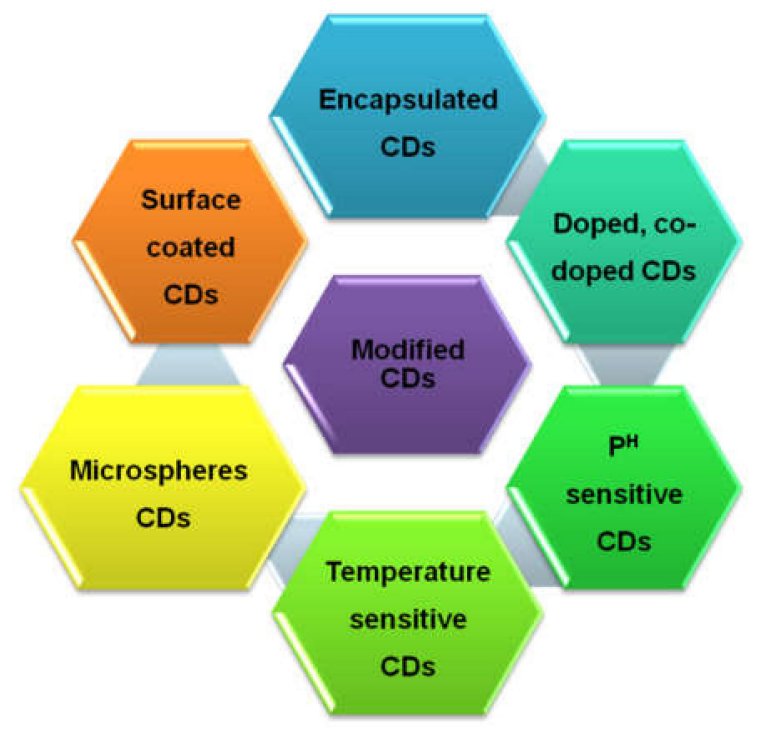

Figure 2. Schematic diagram of different types of CDs obtained through different synthesis strategies.

\section{Common Methodology for the Surface Engineering of CDs}

CDs having the desired functionality for the intended application can be obtained through surface functionalization, commonly known as surface passivation [82-86]. Specific chemical interactions, such as covalent bonding, electrostatic interaction, or pi-pi conjugation, are used for surface functionalization of CDs. For example, in previous research, carbodiimide covalent crosslinking utilized the surface carboxylic group $(-\mathrm{COOH})$ following reaction with an amine group to covalently conjugate $\mathrm{CDs}$ with a therapeutic agent. The available- $\mathrm{COOH}$ group on $\mathrm{CDs}$ allows this type of zero-length carboxyl-to-amine crosslink covalent bonding to occur. In this case, the conjugation protocol using 1-ethyl-3-(3-dimethyl-aminopropyl) carbodiimide hydrochloride (EDC) and $\mathrm{N}$-hydroxysuccinimide (NHS) reagents is a general method of practice in experiments. In this regard, protein-based therapeutics and small-molecule drugs that have a free amine group are favorable for this kind of conjugation. At the end of the reaction, the resultant conjugated products were dialyzed for purification and freeze-dried for storage and further study $[87,88]$.

Moreover, the weak chemical interaction, including pi-pi stacking and electrostatic interaction, can empower the functionalization process. For example, the sp ${ }^{2}$ hybridized $\mathrm{C}=\mathrm{C}$ pi $(\pi)$ bond of $\mathrm{CDs}$ is able to undergo pi-pi conjugation with a desired molecule having similar pi bonds. For instance, the anticancer doxorubicin (DOX) can be combined with CDs. This type of strategy also enables the conjugation of other small-molecule dyes with CDs. Moreover, the negative surface charges of CDs have a potential role in electrostatic interaction with positively charged therapeutic agents. The positive charges of folic acid (FA) and polyethyleneimine (PEI) are a few such examples. Their weak interactions with different bioactive agents allow controlled release from the CDs' surface at a predetermined rate (Figure 3) [89]. 


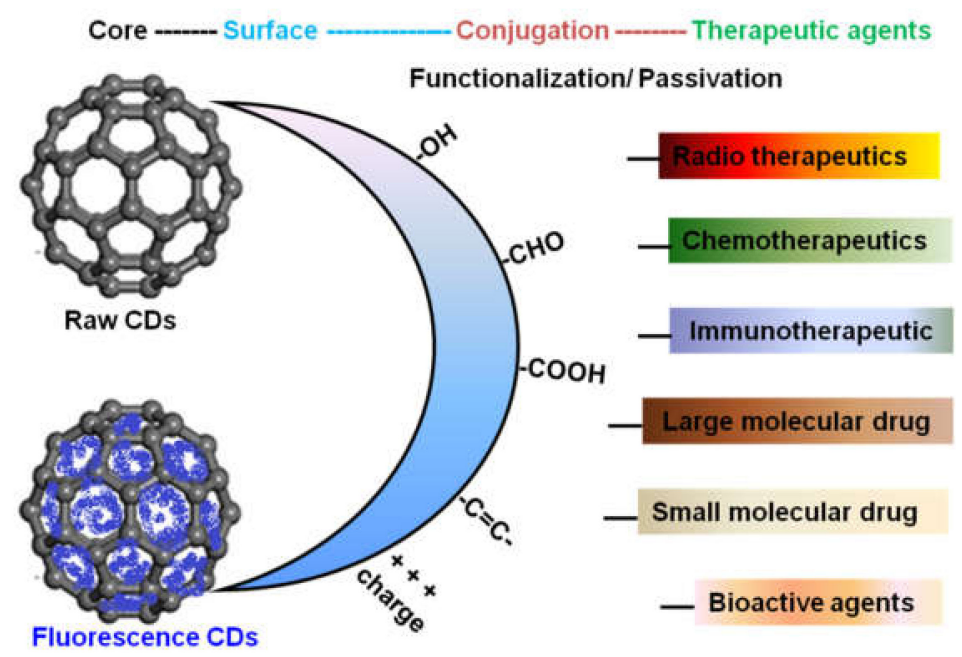

Figure 3. The surface-engineered CDs for the functionalization of therapeutic and diagnostic applications.

\section{Unique Properties of Surface-Functionalized CDs}

The CD surface has been altered by complex engineering with small organic molecules, metallic nanoparticles, polymeric materials, and so on, which are conjugated via covalent, hydrogen, and ionic bonds to enhance water solubility and photoluminescence properties [87]. Surface-engineered CDs exhibit more targeted drug delivery, diagnostic imaging, and target-modulated sensing (Figure 3) [88]. The improved genre of CDs is produced via various surface passivation and fabrication methods, giving them better luminescent properties than the unmodified ones. The final quantum yields (\%) of the produced CDs vary depending on the initial source materials that have been used. With advanced surface functionalization, the upgraded version of CDs can be generated for diverse theranostic purposes [90-92].

\section{Results of CDs in Diagnosis and Drug Delivery}

\subsection{In Vitro Study}

Carbon dots (CDs) are considered as excellent luminescence probes for bioimaging due to their unique optical properties, size tuning capacity, surface functionalization capacity, and reduced photo blinking and photobleaching characteristics. CDs have shown a range of colors from blue to red, and even NIR emissions, based on different synthesis approaches. Various in vitro studies have shown low toxicity or nontoxicity of CDs compared to other fluorescent nanomaterials [87]. Many in vitro studies confirmed the internalization of CDs not only in the cytoplasm, but also in mitochondria. Recent studies demonstrated that CDs could also penetrate in vitro within two hours of incubation through a nonendocytosis pathway due to their smaller size and being organic in nature [88]. The quantitative cellular accumulation of bare CDs and CDs with attached targeting ligand on healthy (MDCK) and cancerous (MDAMB and A-549) cells previously demonstrated more efficient uptake in cancerous cells than in healthy cells. The considerable amount of ligand-attached CDs taken up by the cancer cells showed target selectively via receptor-mediated endocytosis. At the same time, the enhanced permeability and retention effect (EPR) could play a significant role in the uptake of nanosized CDs inside the tumor [14,93-122]. The in vitro studies' reports on the cell tracking and biological processing of CDs are a key indicator of predicting the success in vivo of any therapeutic material.

\subsection{In Vivo Study}

Fluorescent materials in the short-wavelength region are not a preferable choice because in vivo bioimaging needed deeper light penetration into the tissue sample. However, most of the existing CDs 
emit a blue color and are excited by shorter wavelengths. The CDs' fluorescence emissions in the red to NIR wavelength for in vivo bioimaging are still most challenging. Several studies conducted on tuning CDs fluorescence emissions in the visible to NIR window are very promising. Otherwise, CDs are very promising mainly due to their small sizes, which confer an enhanced permeability and retention (EPR) effect to target the malignant tumors. CDs can be readily excreted by the urinary system to limit in vivo toxicity (Figure 4). Moreover, CDs are very promising as a carrier system that can deliver different therapeutic agents. CDs conjugated with therapeutic agents attempt to serve a theranostic function in the delivery of chemotherapy, photodynamic therapy (PDT), photothermal therapy (PTT), gene therapy, and radiation therapy [7,123-127].
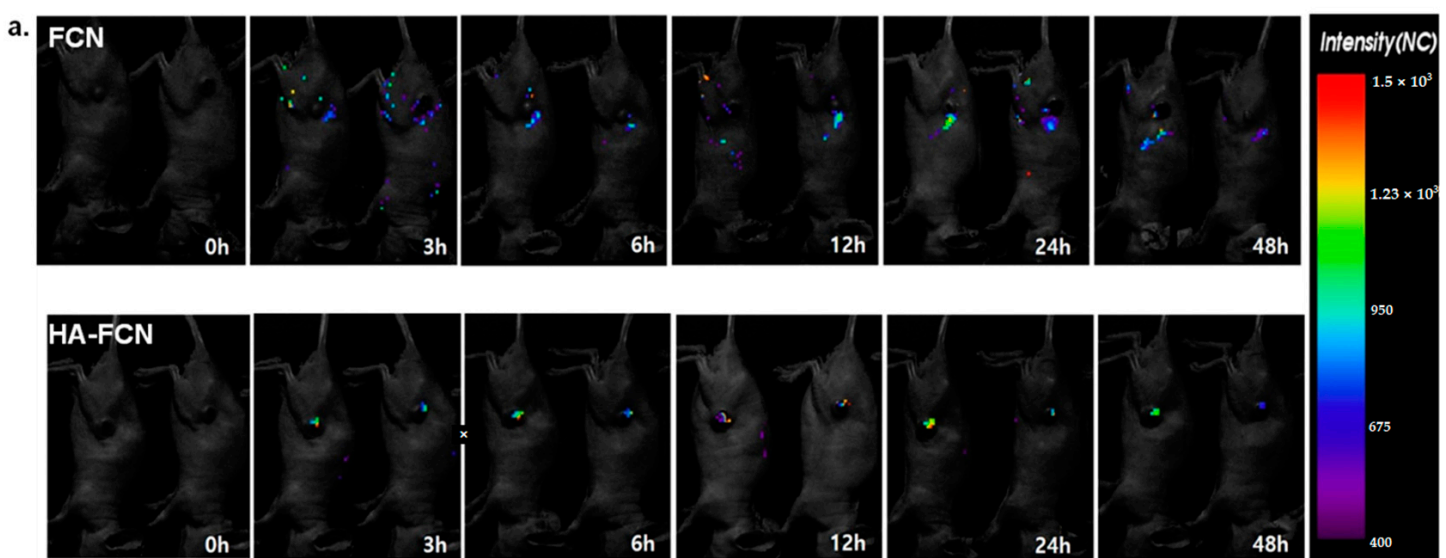

b.
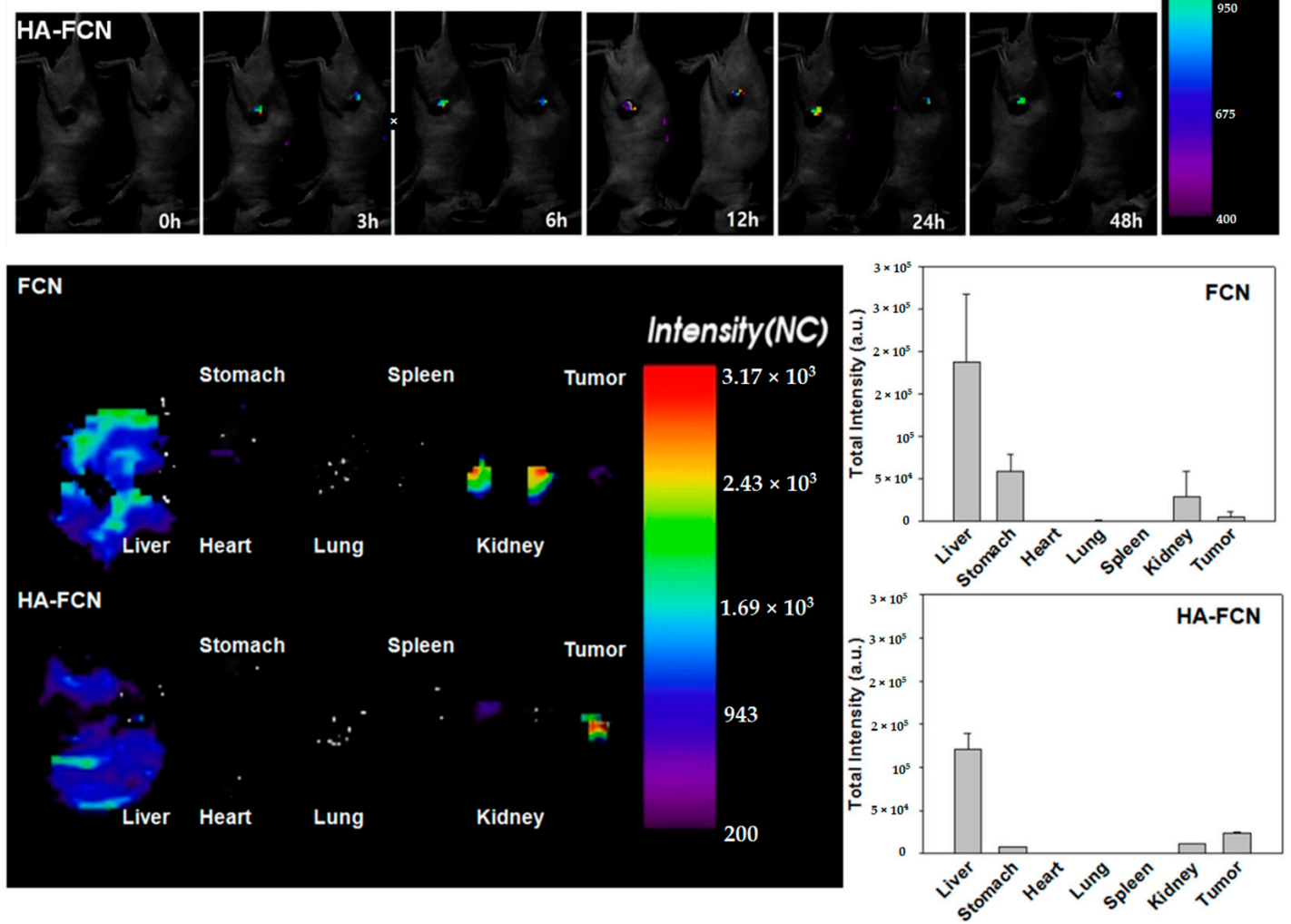

Figure 4. (a) In vivo biodistribution and corresponding intensities of CDs from FCN and HA-FCN of tumor-bearing nude nice at $0 \mathrm{~h}, 3 \mathrm{~h}, 6 \mathrm{~h}, 12 \mathrm{~h}$, and $24 \mathrm{~h}$. after administration (b) The ex vivo biodistribution and corresponding intensities of FCN and HA-FCN from the liver, heart, lung, spleen, kidney and tumor, respectively, after dissection, with the normalized intensity from dissected organs. (C) The Royal Society of Chemistry [13].

The bioimaging and tracking of stem cells by CDs is another branch that remains almost unexplored. A small number of promising studies have revealed that CDs can penetrate inside stem cells through endocytosis and remain in the cytoplasm. The presence of CDs did not affect cell differentiation and expression of the cell-specific marker. Furthermore, the study of cancer stem cells allows us to predict the tumor area's heterogeneous nature. In this context, the pancreatic cancer stem cells labeled by CDs-rhodamine confirmed internalization and allowed the evaluation of cellular morphology and 
detection of $\mathrm{Fe}^{3+}$ ions. The internalization of $\mathrm{CDs}$ might be due to the nanosize, physicochemical properties, and surface charge of the nanoparticles. The scope of $\mathrm{CDs}^{\prime}$ rational design is expected to complement the existing typical fluorescent probes for biomedical applications $[7,128,129]$.

Moreover, the irradiation of photoactive CDs with nanosecond pulse laser light leads to the generation of heat and acoustic waves that can be employed for photoacoustic (PA) imaging. CDs are an emerging noninvasive class of imaging materials that provides high-resolution images in deep tissues due to a laser-induced photoacoustic effect [71,130]. High detection sensitivity, quantifiability, and increased penetration capacity of single-photon emission computed tomography (SPECT), positron-electron tomography (PET), and magnetic resonance imaging (MRI) combined with the multifunctional and tunable characteristics of CDs offer massive opportunities in early detection of the tumor. CDs can also offer individualized treatment monitoring, patient screening, and dose optimization, which might provide guidance in overcoming particular crucial challenges in medical and pharmaceutical science (Figure 5) [131,132].

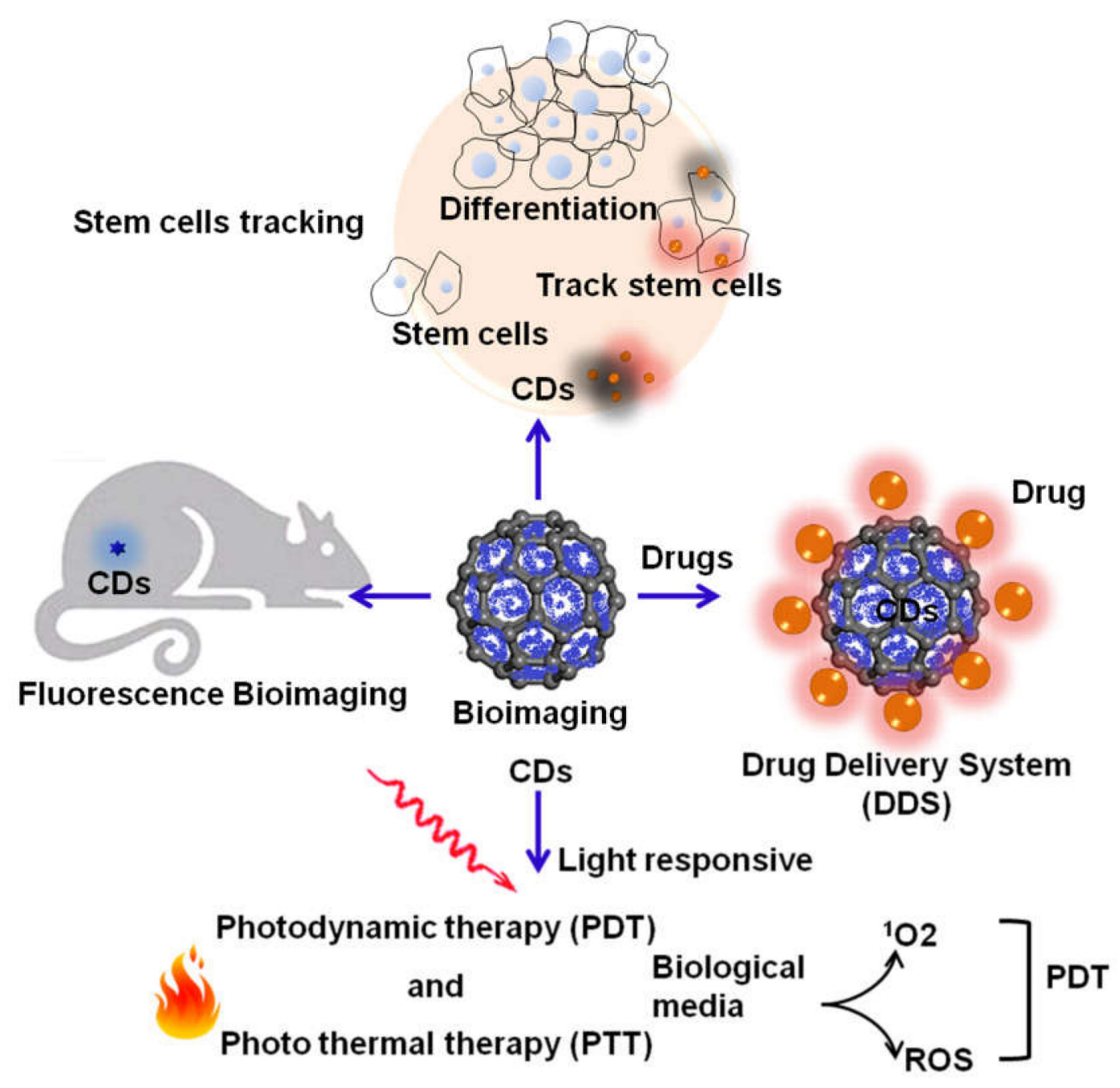

Figure 5. The application scope for carbon dots (CDs) as multipurpose theranostic agents.

The specific chemical bonding, pi-pi stacking, and hydrophobic interaction or nonspecific surface absorptions have allowed different anticancer molecules to be covalently conjugated to CDs. Furthermore, the anticancer drug-conjugated CDs can increase the aqueous solubility of doxorubicin (DOX), paclitaxel (PTX), oxaliplatin (OXA), and other hydrophobic drugs $[8,133]$. This is an up-and-coming technique for the enhanced permeability and retention (EPR)-based passive targeting of tumors. Furthermore, the introduction of a targeting ligand with a CDs drug delivery system 
also offers an active targeting strategy. The active targeting goal can be achieved by chemical conjugation of folic acid (FA), hyaluronic acid (HA), aptamers, RGD (Arginine-Glycine-Aspartate) peptide, and antibodies [13]. Like anticancer drug delivery, CDs can also be used in the field of gene delivery. In one study, the positive surface charge of polyethyleneimine (PEI)-fabricated CDs was conjugated with negatively charge DNA. These electrostatically bonded CDs-DNA could transfer genes inside the cells within three hours of transfection. In both drug and gene delivery, CDs can maintain fluorescence properties under different excitation wavelengths, demonstrating their potential in the development of advanced diagnostic tools [14].

Moreover, light-triggered photosensitizing properties of CDs, alone or in combination with photosensitizing agents, can generate reactive oxygen species (ROS) in tumor cells. This is another branch of cancer therapy, commonly known as near-infrared (NIR) light-irradiated photodynamic therapy (PDT) (Figure 5) [134-141]. For example, PEG (polyethylene glycol)-functionalized CDs with the photosensitizer chlorin (Ce6), protoporphyrin, or zinc phthalocyanine $(\mathrm{ZnPc})$ generated ROS under the excitation of CDs for targeted PDT [142,143].

Furthermore, it has been observed that high levels of nitric oxide (NO) can be cytostatic or cytotoxic for tumor cells. However, the short half-life (t1/2) of NO and bioactivities in other tissues have limited its profound therapeutic implications. In this context, CDs with photoresponsive 4-nitro-3-(trifluoromethyl) aniline attached have shown phototriggered NO release inside the cancer cells [144].

Like PDT, the NIR-responsive photothermal therapies (PTT) can hyperthermally kill the targeted cancer cells. Different carbon-based nanomaterials can absorb NIR light in the electromagnetic spectrum and convert it into heat to thermally destroy the malignant cells (Figure 5). For example, carbonized polydopamine $(\mathrm{pDa})$ has demonstrated NIR-responsive photothermal conversion and multicolored fluorescence emission under different excitation wavelengths [41,145-147]. Moreover, a CD-based hybrid system can simultaneously perform PDT, PTT, and pH- or NIR-responsive drug release. Such a multifunctional smart delivery system enables synergistic cancer therapy [148]. For example, CDs nanogels with integrated PEG-chitosan have shown dual $\mathrm{pH}$ - and NIR light-responsive drug release and PTT against tumor cells. In another attempt, carbonized fluorescence hyaluronic acid (HA-FCN)-conjugated boronic acid (BA) decorated with $\beta$-cyclodextrin showed promise as a multiresponsive paclitaxel (PTX) DDS (drug delivery system) (Figure 6). This kind of DDS exploits an acidic $\mathrm{pH}$-dependent and remote external NIR-responsive on-demand cooperative controlling strategy [13]. Development of such collaborative stimulus-responsive DDSs having bioimaging potentiality is a promising method for chemotherapeutic release that can be adjusted according to physiological needs [149]. 


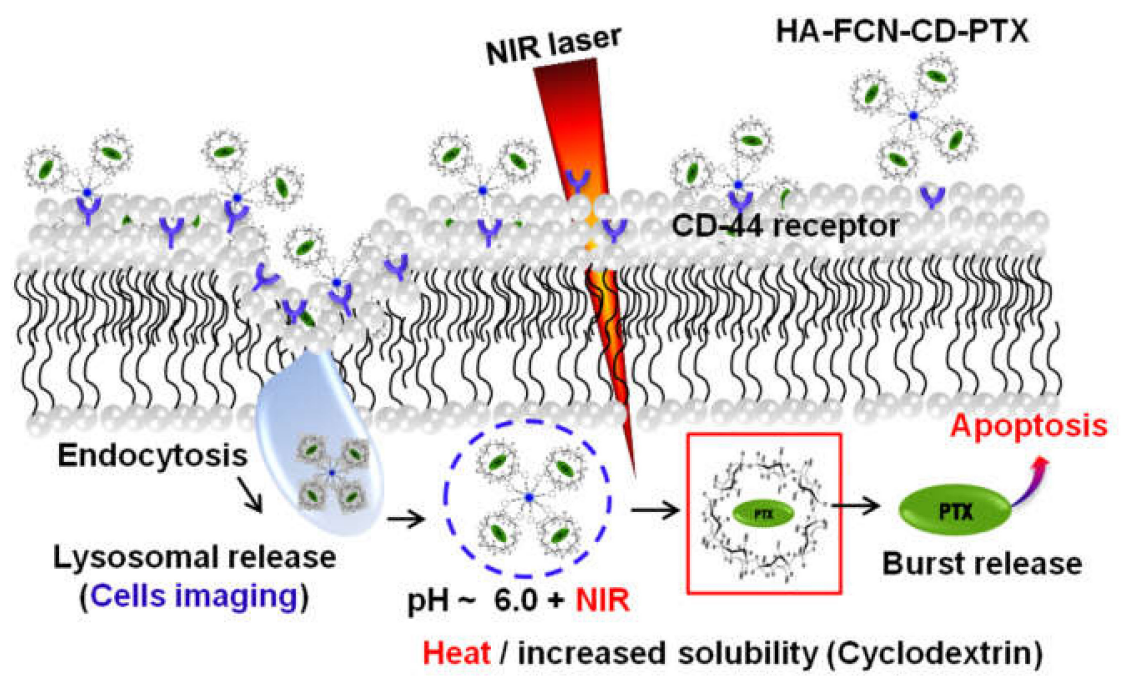

Figure 6. The schematic illustration of multistimulus-responsive carbonized fluorescence hyaluronic acid (HA-FCN) conjugated boronic acid (BA) decorated with $\beta$-cyclodextrin used for the delivery of paclitaxel (PTX). (C) The Royal Society of Chemistry [14].

The unique photoluminescence properties, suitable size, excellent DNA/RNA condensation capacity, and extraordinary biocompatibility of CDs mean they are considered as remarkable aids for delivering nucleic acids. Moreover, doping of CDs with various heteroatoms and surface-modified cationic CDs can make them capable of acting as image trackable nucleic acid nanocarriers. This property can possess high transfection efficiency and has been utilized for plasmid DNA and siRNA (small interfering RNA) delivery, thus bringing revolutionary changes in gene therapy (Figure 7) [150].

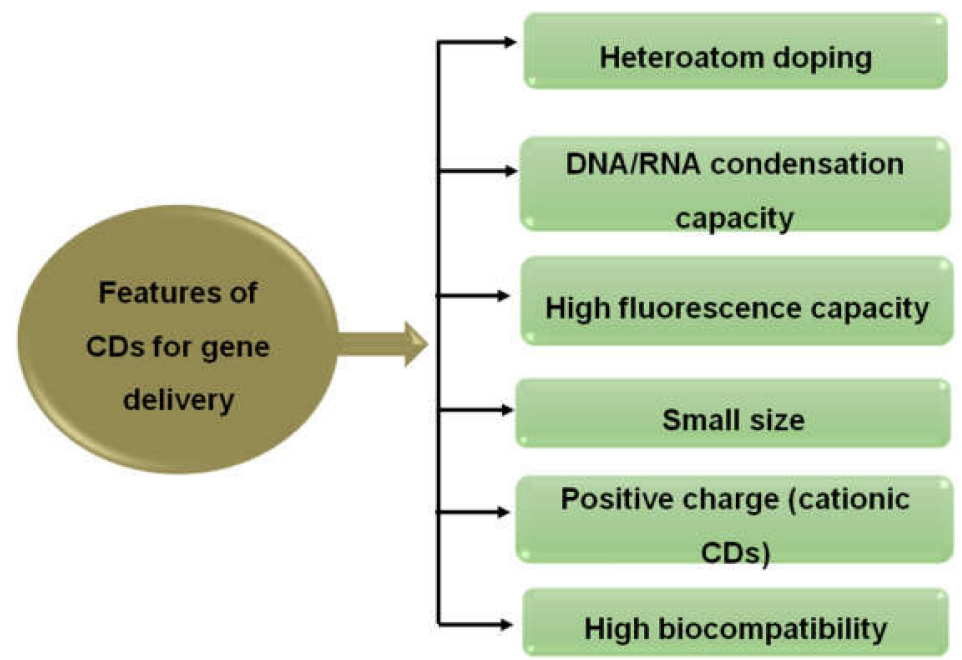

Figure 7. Essential features of CDs necessary for the gene delivery system.

\section{Challenges and Limitations of the Usage of CDs in Cancer Therapy}

Although huge numbers of $\mathrm{CD}$ applications have been possible to establish to date, there are some in vivo limitations that need to be overcome. The mechanism of CDs is debatable due to change in synthetic routes, initial synthetic materials used, surface functional groups, and wide range of size distribution. Some factors, such as toxicity, blood compatibility, rapid excretion from the body, suitable hydrodynamic diameter, and the lowest possible adsorption of proteins, must be taken into account while designing CDs [151,152]. The clinical feasibility studies have reported the concentration-dependent in vivo effects of $\mathrm{CDs}$ on the blood components. The concentration of CDs 
above $0.1 \mathrm{mg} / \mathrm{mL}$ shows disruptions and lysis of (red blood cells) RBC, activation of the complement system, and triggering of the platelet-activated coagulation function [153-156].

Therefore, the prospect of $C D$ synthesis and fabrication methods should be explored more so that the highest quantum yield (\%) of CDs can be produced for the proper use of therapeutic carriers. Besides, most CDs have an absorption band in the short wavelength region (green and blue), which is unsuitable for in vivo imaging; hence, synthesis of CDs which emit light in the longer wavelength region is desirable [157-162]. More research studies should be carried out upon doped and codoped CDs with multicolor emissive properties. They can exhibit higher photoluminescence effects and can be utilized in different bioimaging and therapeutic applications [163-194]. Furthermore, the fundamental mechanism of how CDs interact with low-energy photons should be explored more in order to facilitate improvement in their optical properties related to image resolution and contrast.

\section{Conclusions}

A collective effort from nanotechnology has required the development of cancer therapeutics to overcome the hurdle of translating CD-based nanomaterials. The preliminary works of CDs are promising because of their small sizes, functionalization potentiality, and the ability to introduce multiple therapeutic agents on their surfaces. Moreover, the photoluminescence properties of CDs play an additional advantage for the bioimaging and diagnosis of tumors. Agents with combined therapeutic and diagnostic functionality are termed theranostic; this captures the main potential of CDs to address the challenges of cancer therapy. It can be a paradigm shift in the way that we treat cancer. Although CD-based cancer therapeutics are in the midst of development, they have the technical capability to develop a brand new DDS that can bring new hope for diagnosing, treating, and preventing cancer soon.

Funding: The corresponding author is thankful to the CTRGC-NSU (CTRG-20/SHLS/01) authority to support study and research in the Department of Pharmaceutical Sciences, North South University, Dhaka, Bangladesh.

Conflicts of Interest: The authors declare no conflict of interest

\section{References}

1. Li, Q.; Ohulchanskyy, T.Y.; Liu, R.; Koynov, K.; Wu, D.; Best, A.; Kumar, R.; Bonoiu, A.; Prasad, P.N. Photoluminescent Carbon Dots as Biocompatible Nanoprobes for Targeting Cancer Cells in Vitro. J. Phys. Chem. C 2010, 114, 12062-12068. [CrossRef]

2. Liang, W.; Bunker, C.E.; Sun, Y.-P. Carbon Dots: Zero-Dimensional Carbon Allotrope with Unique Photoinduced Redox Characteristics. ACS Omega 2020, 5, 965-971. [CrossRef] [PubMed]

3. Baker, S.N.; Baker, G.A. Luminescent Carbon Nanodots: Emergent Nanolights. Angew. Chem. Int. Ed. 2010, 49, 6726-6744. [CrossRef] [PubMed]

4. Zhang, X.; Hou, L.; Samorì, P. Coupling carbon nanomaterials with photochromic molecules for the generation of optically responsive materials. Nat. Commun. 2016, 7, 11118. [CrossRef]

5. LeCroy, G.E.; Yang, S.-T.; Yang, F.; Liu, Y.; Fernando, K.A.S.; Bunker, C.E.; Hu, Y.; Luo, P.G.; Sun, Y.-P. Functionalized carbon nanoparticles: Syntheses and applications in optical bioimaging and energy conversion. Coord. Chem. Rev. 2016, 320, 66-81. [CrossRef]

6. Wang, H.; Mararenko, A.; Cao, G.; Gai, Z.; Hong, K.; Banerjee, P.; Zhou, S. Multifunctional 1D Magnetic and Fluorescent Nanoparticle Chains for Enhanced MRI, fluorescent Cell Imaging, And Combined Photothermal/Chemotherapy. ACS Appl. Mater. Interfaces 2014, 6, 15309-15317. [CrossRef] [PubMed]

7. Yuan, F.; Li, S.; Fan, Z.; Yang, S.; Fan, L.; Yang, S. Shining carbon dots: Synthesis and biomedical and optoelectronic applications. Nano Today 2016, 11, 565-586. [CrossRef]

8. Kang, E.B.; Sharker, S.M.; In, I.; Park, S.Y. Pluronic mimicking fluorescent carbon nanoparticles conjugated with doxorubicin via acid-cleavable linkage for tumor-targeted drug delivery and bioimaging. J. Ind. Eng. Chem. 2016, 43, 150-157. [CrossRef] 
9. Ghosh, S.; Chizhik, A.M.; Karedla, N.; Dekaliuk, M.O.; Gregor, I.; Schuhmann, H.; Seibt, M.; Bodensiek, K.; Schaap, I.A.T.; Schulz, O.; et al. Photoluminescence of Carbon Nanodots: Dipole Emission Centers and Electron-Phonon Coupling. Nano Lett. 2014, 14, 5656-5661. [CrossRef]

10. LeCroy, G.E.; Wang, P.; Bunker, C.E.; Fernando, K.S.; Liang, W.; Ge, L.; Reibold, M.; Sun, Y.-P. Hybrid carbon dots platform enabling opportunities for desired optical properties and redox characteristics by-design. Chem. Phys. Lett. 2019, 724, 8-12. [CrossRef]

11. Yang, S.-T.; Cao, L.; Luo, P.G.; Lu, F.; Wang, X.; Wang, H.; Meziani, M.J.; Liu, Y.; Qi, G.; Sun, Y.-P. Carbon Dots for Optical Imaging in Vivo. J. Am. Chem. Soc. 2009, 131, 11308-11309. [CrossRef] [PubMed]

12. Zhou, B.; Guo, Z.; Lin, Z.; Zhang, L.; Jiang, B.-P.; Shen, X.-C. Recent insights into near-infrared light-responsive carbon dots for bioimaging and cancer phototherapy. Inorg. Chem. Front. 2019, 6, 1116-1128. [CrossRef]

13. Sharker, S.M.; Kim, S.M.; Lee, J.E.; Jeong, J.H.; In, I.; Lee, K.D.; Lee, H.; Park, S.Y. In situ synthesis of luminescent carbon nanoparticles toward target bioimaging. Nanoscale 2015, 7, 5468-5475. [CrossRef] [PubMed]

14. Sharker, S.M.; Kim, S.M.; In, I.; Lee, H.; Park, S.Y. Target delivery of $\beta$-cyclodextrin/paclitaxel complexed fluorescent carbon nanoparticles: Externally NIR light and internally $\mathrm{pH}$ sensitive-mediated release of paclitaxel with bio-imaging. J. Mater. Chem. B 2015, 3, 5833-5841. [CrossRef] [PubMed]

15. Sharker, S.M.; Lee, J.E.; Kim, S.H.; Jeong, J.H.; In, I.; Lee, H.; Park, S.Y. pH triggered in vivo photothermal therapy and fluorescence nanoplatform of cancer based on responsive polymer-indocyanine green integrated reduced graphene oxide. Biomaterials 2015, 61, 229-238. [CrossRef] [PubMed]

16. Sharker, S.M.; Kim, S.M.; Lee, J.E.; Choi, K.H.; Shin, G.; Lee, S.; Lee, K.D.; Jeong, J.H.; Lee, H.; Park, S.Y. Functionalized biocompatible $\mathrm{WO}_{3}$ nanoparticles for triggered and targeted in vitro and in vivo photothermal therapy. J. Control. Release 2015, 217, 211-220. [CrossRef]

17. Ali, E.S.; Sharker, S.M.; Islam, M.T.; Khan, I.N.; Shaw, S.; Rahman, A.; Uddin, S.J.; Shill, M.C.; Rehman, S.; Das, N.; et al. Targeting cancer cells with nanotherapeutics and nanodiagnostics: Current status and future perspectives. In Seminars in Cancer Biology; Academic Press: Cambridge, MA, USA, 2020. [CrossRef]

18. Xie, J.; Lee, S.; Chen, X. Nanoparticle-based theranostic agents. Adv. Drug Deliv. Rev. 2010, 62, $1064-1079$. [CrossRef]

19. Zeng, Q.; Shao, D.; He, X.; Ren, Z.; Ji, W.; Shan, C.; Qu, S.; Li, J.; Chen, L.; Li, Q. Carbon dots as a trackable drug delivery carrier for localized cancer therapy in vivo. J. Mater. Chem. B 2016, 4, 5119-5126. [CrossRef]

20. Veeramani, V.; Bao, Z.; Chan, M.-H.; Wang, H.-C.; Jena, A.; Chang, H.; Hu, S.-F.; Liu, R.-S. Quantum dots for light conversion, therapeutic and energy storage applications. J. Solid State Chem. 2019, 270, 71-84. [CrossRef]

21. Kirchner, C.; Liedl, T.; Kudera, S.; Pellegrino, T.; Muñoz Javier, A.; Gaub, H.E.; Stölzle, S.; Fertig, N.; Parak, W.J. Cytotoxicity of colloidal CdSe and CdSe/ZnS nanoparticles. Nano Lett. 2005, 5, 331-338. [CrossRef]

22. Resch-Genger, U.; Grabolle, M.; Cavaliere-Jaricot, S.; Nitschke, R.; Nann, T. Quantum dots versus organic dyes as fluorescent labels. Nat. Methods 2008, 5, 763-775. [CrossRef] [PubMed]

23. Choi, H.S.; Liu, W.; Misra, P.; Tanaka, E.; Zimmer, J.P.; Ipe, B.I.; Bawendi, M.G.; Frangioni, J.V. Renal clearance of quantum dots. Nat. Biotechnol. 2007, 25, 1165-1170. [CrossRef] [PubMed]

24. Du, J.; Xu, N.; Fan, J.; Sun, W.; Peng, X. Carbon Dots for In Vivo Bioimaging and Theranostics. Small 2019, 15, e1805087. [CrossRef] [PubMed]

25. Zhao, A.; Chen, Z.; Zhao, C.; Gao, N.; Ren, J.; Qu, X. Recent advances in bioapplications of C-dots. Carbon 2015, 85, 309-327. [CrossRef]

26. Zhang, J.; Yu, S.-H. Carbon dots: Large-scale synthesis, sensing and bioimaging. Mater. Today 2016, 19, 382-393. [CrossRef]

27. Zhou, J.; Sheng, Z.; Han, H.; Zou, M.; Li, C. Facile synthesis of fluorescent carbon dots using watermelon peel as a carbon source. Mater. Lett. 2012, 66, 222-224. [CrossRef]

28. Jeong, C.J.; Roy, A.K.; Kim, S.H.; Lee, J.E.; Jeong, J.H.; In, I.; Park, S.Y. Fluorescent carbon nanoparticles derived from natural materials of mango fruit for bio-imaging probes. Nanoscale 2014, 6, 15196-15202. [CrossRef]

29. Sk, P.; Jaiswal, A.; Paul, A.; Ghosh, S.S.; Chattopadhyay, A. Presence of Amorphous Carbon Nanoparticles in Food Caramels. Sci. Rep. 2012, 2, 383. [CrossRef]

30. Wang, J.; Wang, C.F.; Chen, S. Amphiphilic egg-derived carbon dots: Rapid plasma fabrication, pyrolysis process, and multicolor printing patterns. Angew. Chem. Int. Ed. 2012, 51, 9297-9301. [CrossRef] 
31. Prasannan, A.; Imae, T. One-Pot Synthesis of Fluorescent Carbon Dots from Orange Waste Peels. Ind. Eng. Chem. Res. 2013, 52, 15673-15678. [CrossRef]

32. Mewada, A.; Pandey, S.; Shinde, S.; Mishra, N.; Oza, G.; Thakur, M.; Sharon, M.; Sharon, M. Green synthesis of biocompatible carbon dots using aqueous extract of Trapa bispinosa peel. Mater. Sci. Eng. C 2013, 33, 2914-2917. [CrossRef] [PubMed]

33. Basu, A.; Suryawanshi, A.; Kumawat, B.; Dandia, A.; Guin, D.; Ogale, S.B. Starch (Tapioca) to carbon dots: An efficient green approach to an on-off-on photoluminescence probe for fluoride ion sensing. Analyst 2015, 140, 1837-1841. [CrossRef] [PubMed]

34. De, B.; Karak, N. A green and facile approach for the synthesis of water soluble fluorescent carbon dots from banana juice. RSC Adv. 2013, 3, 8286-8290. [CrossRef]

35. Song, Y.; Xu, Y.; Li, Z.; Qu, L.; Zhu, C.; Ye, R.; Li, S.; Du, D.; Lin, Y. Highly photoluminescent carbon dots derived from linseed and their applications in cellular imaging and sensing. J. Mater. Chem. B 2018, 6, 3181-3187. [CrossRef] [PubMed]

36. Zhang, M.; Zhao, Y.; Cheng, J.; Liu, X.; Wang, Y.; Yan, X.; Zhang, Y.; Lu, F.; Wang, Q.; Qu, H. Novel carbon dots derived from Schizonepetae Herba Carbonisata and investigation of their haemostatic efficacy. Artif. Cells Nanomed. Biotechnol. 2017, 46,1-10. [CrossRef] [PubMed]

37. Wang, D.; Wang, X.; Guo, Y.; Liu, W.; Qin, W. Luminescent properties of milk carbon dots and their sulphur and nitrogen doped analogues. RSC Adv. 2014, 4, 51658-51665. [CrossRef]

38. Kohri, M.; Nannichi, Y.; Taniguchi, T.; Kishikawa, K. Biomimetic non-iridescent structural color materials from polydopamine black particles that mimic melanin granules. J. Mater. Chem. C 2015, 3, 720-724. [CrossRef]

39. Yang, Y.; Cui, J.; Zheng, M.; Hu, C.; Tan, S.; Xiao, Y.; Yang, Q.; Liu, Y. One-step synthesis of amino-functionalized fluorescent carbon nanoparticles by hydrothermal carbonization of chitosan. Chem. Commun. 2012, 48, 380-382. [CrossRef]

40. Wu, T.-F.; Hong, J.-D. Dopamine-Melanin Nanofilms for Biomimetic Structural Coloration. Biomacromolecules 2015, 16, 660-666. [CrossRef]

41. Kim, S.H.; Sharker, S.M.; Lee, H.; In, I.; Lee, K.D.; Park, S.Y. Photothermal conversion upon near-infrared irradiation of fluorescent carbon nanoparticles formed from carbonized polydopamine. RSC Adv. 2016, 6, 61482-61491. [CrossRef]

42. Liu, H.; Li, Z.; Sun, Y.; Geng, X.; Hu, Y.; Meng, H.; Ge, J.; Qu, L. Synthesis of Luminescent Carbon Dots with Ultrahigh Quantum Yield and Inherent Folate Receptor-Positive Cancer Cell Targetability. Sci. Rep. 2018, 8 , 1-8. [CrossRef] [PubMed]

43. Sun, D.; Ban, R.; Zhang, P.-H.; Wu, G.-H.; Zhang, J.-R.; Zhu, J.-J. Hair fiber as a precursor for synthesizing of sulfur- and nitrogen-co-doped carbon dots with tunable luminescence properties. Carbon 2013, 64, 424-434. [CrossRef]

44. Zhang, Z.; Hao, J.; Zhang, J.; Zhang, B.; Tang, J. Protein as the source for synthesizing fluorescent carbon dots by a one-pot hydrothermal route. RSC Adv. 2012, 2, 8599-8601. [CrossRef]

45. Liu, R.; Wu, D.; Liu, S.; Koynov, K.; Knoll, W.; Li, Q. An aqueous route to multicolor photoluminescent carbon dots using silica spheres as carriers. Angew. Chem. Int. Ed. 2009, 48, 4598-4601. [CrossRef]

46. Zhang, S.; He, Q.; Li, R.; Wang, Q.; Hu, Z.; Liu, X.; Chang, X. Study on the fluorescence carbon nanoparticles. Mater. Lett. 2011, 65, 2371-2373. [CrossRef]

47. Gu, J.; Zhang, X.; Pang, A.; Yang, J. Facile synthesis and photoluminescence characteristics of blue-emitting nitrogen-doped graphene quantum dots. Nanotechnology 2016, 27, 165704. [CrossRef]

48. Hu, S.-L.; Niu, K.-Y.; Sun, J.; Yang, J.; Zhao, N.-Q.; Du, X.-W. One-step synthesis of fluorescent carbon nanoparticles by laser irradiation. J. Mater. Chem. 2009, 19, 484-488. [CrossRef]

49. Liu, H.; Ye, T.; Mao, C. Fluorescent carbon nanoparticles derived from candle soot. Angew. Chem. 2007, 119, 6593-6595. [CrossRef]

50. Li, H.; He, X.; Liu, Y.; Yu, H.; Kang, Z.; Lee, S.-T. Synthesis of fluorescent carbon nanoparticles directly from active carbon via a one-step ultrasonic treatment. Mater. Res. Bull. 2011, 46, 147-151. [CrossRef]

51. Hens, S.C.; Lawrence, W.G.; Kumbhar, A.S.; Shenderova, O. Photoluminescent Nanostructures from Graphite Oxidation. J. Phys. Chem. C 2012, 116, 20015-20022. [CrossRef] 
52. Huang, J.J.; Zhong, Z.F.; Rong, M.Z.; Zhou, X.; Chen, X.D.; Zhang, M.Q. An easy approach of preparing strongly luminescent carbon dots and their polymer based composites for enhancing solar cell efficiency. Carbon 2014, 70, 190-198. [CrossRef]

53. Luo, B.; Yang, H.; Zhou, B.; Ahmed, S.M.; Zhang, Y.; Liu, H.; Liu, X.; He, Y.; Xia, S. Facile Synthesis of Luffa Sponge Activated Carbon Fiber Based Carbon Quantum Dots with Green Fluorescence and Their Application in Cr(VI) Determination. ACS Omega 2020, 5, 5540-5547. [CrossRef]

54. Hu, Y.; Yang, J.; Tian, J.; Jia, L.; Yu, J.-S. Waste frying oil as a precursor for one-step synthesis of sulfur-doped carbon dots with $\mathrm{pH}$-sensitive photoluminescence. Carbon 2014, 77, 775-782. [CrossRef]

55. Chandra, S.; Das, P.; Bag, S.; Laha, D.; Pramanik, P. Synthesis, functionalization and bioimaging applications of highly fluorescent carbon nanoparticles. Nanoscale 2011, 3, 1533-1540. [CrossRef] [PubMed]

56. Zhu, H.; Wang, X.; Li, Y.; Wang, Z.; Yang, F.; Yang, X. Microwave synthesis of fluorescent carbon nanoparticles with electrochemiluminescence properties. Chem. Commun. 2009, 2009, 5118-5120. [CrossRef] [PubMed]

57. Jang, M.-H.; Hwang, Y.S. Effects of functionalized multi-walled carbon nanotubes on toxicity and bioaccumulation of lead in Daphnia magna. PLoS ONE 2018, 13, e0194935. [CrossRef] [PubMed]

58. Bhunia, S.K.; Saha, A.; Maity, A.R.; Ray, S.C.; Jana, N.R. Carbon Nanoparticle-based Fluorescent Bioimaging Probes. Sci. Rep. 2013, 3, 1-7. [CrossRef] [PubMed]

59. Qin, X.; Lu, W.; Asiri, A.M.; Al-Youbi, A.O.; Cheng, N. Microwave-assisted rapid green synthesis of photoluminescent carbon nanodots from flour and their applications for sensitive and selective detection of mercury(II) ions. Sens. Actuators B Chem. 2013, 184, 156-162. [CrossRef]

60. Mazrad, Z.A.I.; Kang, E.B.; Nuraeni, N.; Lee, G.; In, I.; Park, S.Y. Temperature-sensitive carbon dots derived from poly(N-isopropylacrylamide) for fluorescence on-off properties. RSC Adv. 2017, 7, 11149-11157. [CrossRef]

61. Kim, Y.K.; Sharker, S.M.; In, I.; Park, S.Y. Surface coated fluorescent carbon nanoparticles/TiO2 as visible-light sensitive photocatalytic complexes for antifouling activity. Carbon 2016, 103, 412-420. [CrossRef]

62. Chae, A.; Choi, Y.; Jo, S.; Paoprasert, P.; Park, S.Y.; In, I. Microwave-assisted synthesis of fluorescent carbon quantum dots from an A 2/B 3 monomer set. RSC Adv. 2017, 7, 12663-12669. [CrossRef]

63. Gu, J.; Wang, W.; Zhang, Q.; Meng, Z.; Jia, X.; Xi, K. Synthesis of fluorescent carbon nanoparticles from polyacrylamide for fast cellular endocytosis. RSC Adv. 2013, 3, 15589. [CrossRef]

64. Hola, K.; Bourlinos, A.B.; Kozak, O.; Berka, K.; Siskova, K.M.; Havrdova, M.; Tucek, J.; Safarova, K.; Otyepka, M.; Giannelis, E.P.; et al. Photoluminescence effects of graphitic core size and surface functional groups in carbon dots: COO- induced red-shift emission. Carbon 2014, 70, 279-286. [CrossRef]

65. Wu, H.; Mi, C.; Huang, H.; Han, B.; Li, J.; Xu, S. Solvothermal synthesis of green-fluorescent carbon nanoparticles and their application. J. Lumin. 2012, 132, 1603-1607. [CrossRef]

66. Pan, D.; Zhang, J.; Li, Z.; Wu, C.; Yan, X.; Wu, M. Observation of pH-, solvent-, spin-, and excitation-dependent blue photoluminescence from carbon nanoparticles. Chem. Commun. 2010, 46, 3681-3683. [CrossRef]

67. Jeong, C.J.; Lee, G.; In, I.; Park, S.Y. Concentration-mediated multicolor fluorescence polymer carbon dots. Luminescence 2015, 31, 897-904. [CrossRef]

68. Roy, A.K.; Kim, S.M.; Paoprasert, P.; Park, S.-Y.; In, I. Preparation of biocompatible and antibacterial carbon quantum dots derived from resorcinol and formaldehyde spheres. RSC Adv. 2015, 5, 31677-31682. [CrossRef]

69. Rahy, A.; Zhou, C.; Zheng, J.; Park, S.; Kim, M.J.; Jang, I.; Cho, S.J.; Yang, D.J. Photoluminescent carbon nanoparticles produced by confined combustion of aromatic compounds. Carbon 2012, 50, 1298-1302. [CrossRef]

70. Guo, Y.; Wang, Z.; Shao, H.; Jiang, X. Hydrothermal synthesis of highly fluorescent carbon nanoparticles from sodium citrate and their use for the detection of mercury ions. Carbon 2013, 52, 583-589. [CrossRef]

71. Dong, Y.; Wang, R.; Li, H.; Shao, J.; Chi, Y.; Lin, X.; Chen, G. Polyamine-functionalized carbon quantum dots for chemical sensing. Carbon 2012, 50, 2810-2815. [CrossRef]

72. Guo, X.; Wang, C.-F.; Yu, Z.-Y.; Chen, L.; Chen, S. Facile access to versatile fluorescent carbon dots toward light-emitting diodes. Chem. Commun. 2012, 48, 2692-2694. [CrossRef] [PubMed]

73. Lin, Z.; Xue, W.; Chen, H.; Lin, J.-M. Peroxynitrous-Acid-Induced Chemiluminescence of Fluorescent Carbon Dots for Nitrite Sensing. Anal. Chem. 2011, 83, 8245-8251. [CrossRef] [PubMed]

74. Yang, P.; Zhu, Z.; Chen, M.; Chen, W.; Zhou, X. Microwave-assisted synthesis of xylan-derived carbon quantum dots for tetracycline sensing. Opt. Mater. 2018, 85, 329-336. [CrossRef] 
75. Li, F.; Yang, D.; Xu, H. Non-Metal-Heteroatom-Doped Carbon Dots: Synthesis and Properties. Chem. Eur. J. 2018, 25, 1165-1176. [CrossRef] [PubMed]

76. Wang, W.; Lu, Y.-C.; Huang, H.; Wang, A.-J.; Chen, J.-R.; Feng, J.-J. Facile synthesis of N, S-codoped fluorescent carbon nanodots for fluorescent resonance energy transfer recognition of methotrexate with high sensitivity and selectivity. Biosens. Bioelectron. 2015, 64, 517-522. [CrossRef] [PubMed]

77. Yanga, X.-C.; Li, Q.; Tang, M.; Yanga, Y.-L.; Yang, W.; Hu, J.-F.; Pu, X.-L.; Liu, J.; Zhao, J.-T.; Zhang, Z.-J. One Stone, Two Birds: $\mathrm{pH}$ - and Temperature-Sensitive Nitrogen-Doped Carbon Dots for Multiple Anticounterfeiting and Multiple Cell Imaging. ACS Appl. Mater. Interfaces 2020, 12, 20849-20858. [CrossRef] [PubMed]

78. Kim, Y.K.; Kang, E.B.; Kim, S.H.; Sharker, S.M.; Kong, B.Y.; In, I.; Lee, K.D.; Park, S.Y. Visible-Light-Driven Photocatalysts of Perfluorinated Silica-Based Fluorescent Carbon Dot/TiO2 for Tunable Hydrophilic-Hydrophobic Surfaces. ACS Appl. Mater. Interfaces 2016, 8, 29827-29834. [CrossRef]

79. Kim, S.H.; Kang, E.B.; Jeong, C.J.; Sharker, S.M.; In, I.; Park, S.Y. Light Controllable Surface Coating for Effective Photothermal Killing of Bacteria. ACS Appl. Mater. Interfaces 2015, 7, 15600-15606. [CrossRef]

80. Suzuki, K.; Malfatti, L.; Carboni, D.; Loche, D.; Casula, M.; Moretto, A.; Maggini, M.; Takahashi, M.; Innocenzi, P. Energy Transfer Induced by Carbon Quantum Dots in Porous Zinc Oxide Nanocomposite Films. J. Phys. Chem. C 2015, 119, 2837-2843. [CrossRef]

81. Mishra, V.; Patil, A.; Thakur, S.; Kesharwani, P. Carbon dots: Emerging theranostic nanoarchitectures. Drug Discov. Today 2018, 23, 1219-1232. [CrossRef]

82. Zuo, P.; Lu, X.; Sun, Z.; Guo, Y.; He, H. A review on syntheses, properties, characterization and bioanalytical applications of fluorescent carbon dots. Microchim. Acta 2015, 183, 519-542. [CrossRef]

83. Huang, G.; Chen, X.; Wang, C.; Zheng, H.; Huang, Z.; Chen, D.; Xie, H. Photoluminescent carbon dots derived from sugarcane molasses: Synthesis, properties, and applications. RSC Adv. 2017, 7, 47840-47847. [CrossRef]

84. Guo, J.; Liu, D.; Filpponen, I.; Johansson, L.-S.; Malho, J.-M.; Quraishi, S.; Liebner, F.W.; Santos, H.A.; Rojas, O.J. Photoluminescent Hybrids of Cellulose Nanocrystals and Carbon Quantum Dots as Cytocompatible Probes for in Vitro Bioimaging. Biomacromolecules 2017, 18, 2045-2055. [CrossRef] [PubMed]

85. Algarra, M.; Pérez-Martín, M.; Cifuentes-Rueda, M.; Jiménez-Jiménez, J.; Da Silva, J.C.G.E.; Bandosz, T.J.; Rodríguez-Castellón, E.; Navarrete, J.T.L.; Casado, J. Carbon dots obtained using hydrothermal treatment of formaldehyde. Cell imaging in vitro. Nanoscale 2014, 6, 9071-9077. [CrossRef]

86. Huo, F.; Liang, W.; Tang, Y.; Zhang, W.; Liu, X.; Pei, D.-S.; Wang, H.; Jia, W.; Jia, P.; Yang, F. Full-color carbon dots with multiple red-emission tuning: On/Off sensors, in vitro and in vivo multicolor bioimaging. J. Mater. Sci. 2019, 54, 6815-6825. [CrossRef]

87. Liu, W.; Li, C.; Ren, Y.; Sun, X.; Pan, W.; Li, Y.; Wang, J.; Wang, W. Carbon dots: Surface engineering and applications. J. Mater. Chem. B 2016, 4, 5772-5788. [CrossRef]

88. Fong, J.F.Y.; Ng, Y.H.; Ng, S.M. Recent Advances in Carbon Dots for Bioanalysis and the Future Perspectives. Carbon Nanomater. Bioimaging Bioanal. Ther. 2018, 203-264. [CrossRef]

89. Lim, S.Y.; Shen, W.; Gao, Z. Carbon quantum dots and their applications. Chem. Soc. Rev. 2015, 44, 362-381. [CrossRef]

90. Hola, K.; Zhang, Y.; Wang, Y.; Giannelis, E.P.; Zboril, R.; Rogach, A.L. Carbon dots—Emerging light emitters for bioimaging, cancer therapy and optoelectronics. Nano Today 2014, 9, 590-603. [CrossRef]

91. Zhou, J.; Zhou, H.; Tang, J.; Deng, S.; Yan, F.; Li, W.; Qu, M. Carbon dots doped with heteroatoms for fluorescent bioimaging: A review. Microchim. Acta 2017, 184, 343-368. [CrossRef]

92. Karthik, S.; Saha, B.; Ghosh, S.K.; Singh, N.D.P. Photoresponsive quinoline tethered fluorescent carbon dots for regulated anticancer drug delivery. Chem. Commun. 2013, 49, 10471-10473. [CrossRef] [PubMed]

93. Li, H.; Shao, F.-Q.; Huang, H.; Feng, J.-J.; Wang, A.-J. Eco-friendly and rapid microwave synthesis of green fluorescent graphitic carbon nitride quantum dots for vitro bioimaging. Sens. Actuators B Chem. 2016, 226, 506-511. [CrossRef]

94. Yang, S.-T.; Wang, X.; Wang, H.; Lu, F.; Luo, P.G.; Cao, L.; Meziani, M.J.; Liu, J.-H.; Liu, Y.; Chen, M.; et al. Carbon Dots as Nontoxic and High-Performance Fluorescence Imaging Agents. J. Phys. Chem. C 2009, 113, 18110-18114. [CrossRef] [PubMed] 
95. Ge, J.; Jia, Q.; Liu, W.; Lan, M.; Zhou, B.; Guo, L.; Zhou, H.; Zhang, H.; Wang, Y.; Gu, Y.; et al. Carbon Dots with Intrinsic Theranostic Properties for Bioimaging, Red-Light-Triggered Photodynamic/Photothermal Simultaneous Therapy In Vitro and In Vivo. Adv. Healthc. Mater. 2016, 5, 665-675. [CrossRef] [PubMed]

96. Gao, W.; Song, H.; Wang, X.; Liu, X.; Pang, X.; Zhou, Y.; Gao, B.; Peng, X. Carbon Dots with Red Emission for Sensing of Pt2+, Au3+, and Pd2+ and Their Bioapplications in Vitro and in Vivo. ACS Appl. Mater. Interfaces 2017, 10, 1147-1154. [CrossRef] [PubMed]

97. Wang, J.; Zhang, P.; Huang, C.; Liu, G.; Leung, K.C.-F.; Wáng, Y.X.J. High Performance Photoluminescent Carbon Dots for In Vitro and In Vivo Bioimaging: Effect of Nitrogen Doping Ratios. Langmuir 2015, 31, 8063-8073. [CrossRef] [PubMed]

98. Ramanan, V.; Thiyagarajan, S.K.; Raji, K.; Suresh, R.; Sekar, R.; Ramamurthy, P. Outright Green Synthesis of Fluorescent Carbon Dots from Eutrophic Algal Blooms for In Vitro Imaging. ACS Sustain. Chem. Eng. 2016, 4, 4724-4731. [CrossRef]

99. Yang, Y.; Kong, W.; Li, H.; Liu, J.; Yang, M.; Huang, H.; Liu, Y.; Wang, Z.; Wang, Z.; Sham, T.-K.; et al. Fluorescent N-Doped Carbon Dots as in Vitro and in Vivo Nanothermometer. ACS Appl. Mater. Interfaces 2015, 7, 27324-27330. [CrossRef]

100. Vasimalai, N.; Vilas-Boas, V.; Gallo, J.; Cerqueira, M.D.F.; Menéndez-Miranda, M.; Fernández, J.M.C.; Diéguez, L.; Espiña, B.; Fernandez-Arguelles, M.T. Green synthesis of fluorescent carbon dots from spices for in vitro imaging and tumour cell growth inhibition. Beilstein J. Nanotechnol. 2018, 9, 530-544. [CrossRef]

101. Pal, T.; Mohiyuddin, S.; Packirisamy, G. Facile and green synthesis of multicolor fluorescence carbon dots from curcumin: In vitro and in vivo bioimaging and other applications. ACS Omega 2018, 3, 831-843. [CrossRef]

102. Gao, P.; Wang, J.; Zheng, M.; Xie, Z. Lysosome targeting carbon dots-based fluorescent probe for monitoring $\mathrm{pH}$ changes in vitro and in vivo. Chem. Eng. J. 2020, 381, 122665. [CrossRef]

103. Atchudan, R.; Edison, T.N.J.I.; Perumal, S.; Lee, Y.R. Indian Gooseberry-Derived Tunable Fluorescent Carbon Dots as a Promise for In Vitro/In Vivo Multicolor Bioimaging and Fluorescent Ink. ACS Omega 2018, 3, 17590-17601. [CrossRef]

104. Zhangab, M.; Zhenga, T.; Shengc, B.; Wub, F.; Zhangb, Q.; Wangb, W.; Shenb, J.; Zhou, N.; Suna, Y. Mn2+ complex-modified polydopamine- and dual emissive carbon dots based nanoparticles for in vitro and in vivo trimodality fluorescent, photothermal, and magnetic resonance imaging. Chem. Eng. J. 2019, 373, 1054-1063. [CrossRef]

105. Sattarahmady, N.; Rezaie-Yazdi, M.; Tondro, G.; Akbari, N. Bactericidal laser ablation of carbon dots: An in vitro study on wild-type and antibiotic-resistant Staphylococcus aureus. J. Photochem. Photobiol. B Biol. 2017, 166, 323-332. [CrossRef]

106. Zhang, Z.; Lei, Y.; Yang, X.; Shi, N.; Geng, L.; Wang, S.; Zhang, J.; Shi, S. High drug-loading system of hollow carbon dots-doxorubicin: Preparation, in vitro release and $\mathrm{pH}$-targeted research. J. Mater. Chem. B 2019, 7, 2130-2137. [CrossRef]

107. Pierrat, P.; Wang, R.; Kereselidze, D.; Lux, M.; Didier, P.; Kichler, A.; Pons, F.; Lebeau, L. Efficient in vitro and in vivo pulmonary delivery of nucleic acid by carbon dot-based nanocarriers. Biomaterials 2015, 51, 290-302. [CrossRef]

108. Huang, S.; Qiu, H.; Xie, J.; Huang, C.; Su, W.; Hu, B.; Huang, S. Systematical investigation of in vitro molecular interaction between fluorescent carbon dots and human serum albumin. RSC Adv. 2016, 6, 44531-44542. [CrossRef]

109. Liu, Y.; Liu, Y.; Park, M.; Park, S.-J.; Zhang, Y.; Akanda, R.; Park, B.-Y.; Kim, H.-Y. Green synthesis of fluorescent carbon dots from carrot juice for in vitro cellular imaging. Carbon Lett. 2017, 21, 61-67. [CrossRef]

110. Ren, W.; Chen, S.; Liao, Y.; Li, S.; Ge, J.; Tao, F.; Huo, Q.; Zhang, Y.; Zhao, Z. Near-infrared fluorescent carbon dots encapsulated liposomes as multifunctional nano-carrier and tracer of the anticancer agent cinobufagin in vivo and in vitro. Colloids Surf. B Biointerfaces 2019, 174, 384-392. [CrossRef]

111. Li, S.; Guo, Z.; Feng, R.; Zhang, Y.; Xue, W.; Liu, Z. Hyperbranched polyglycerol conjugated fluorescent carbon dots with improved in vitro toxicity and red blood cell compatibility for bioimaging. RSC Adv. 2017, 7, 4975-4982. [CrossRef]

112. Sachdev, A.; Matai, I.; Gopinath, P. Dual-functional carbon dots-silver@zinc oxide nanocomposite: In vitro evaluation of cellular uptake and induction of apoptosis. J. Mater. Chem. B 2015, 3, 1217-1229. [CrossRef] [PubMed] 
113. Vaishnav, S.K.; Karbhal, I.; Satnami, M.L.; Ghosh, K.K. Spectroscopic studies on in vitro molecular interaction of highly fluorescent carbon dots with different serum albumins. J. Mol. Liq. 2018, 255, 279-287. [CrossRef]

114. Qin, K.; Zhang, D.; Ding, Y.; Zheng, X.; Xiang, Y.; Hua, J.; Zhang, Q.; Ji, X.; Li, B.; Wei, Y. Applications of hydrothermal synthesis of Escherichia coli derived carbon dots in in vitro and in vivo imaging and p-nitrophenol detection. Analyst 2020, 145, 177-183. [CrossRef] [PubMed]

115. Krishna, A.S.; Radhakumary, C.; Sreenivasan, K. In vitro detection of calcium in bone by modified carbon dots. Analyst 2013, 138, 7107. [CrossRef]

116. Wang, Z.; Zhu, R.; Wang, M.; Liang, P.; Qian, Y.; Wang, S. Fluorescent carbon dots from antineoplastic drug etoposide for bioimaging in vitro and in vivo. J. Mater. Chem. B 2017, 5, 7796-7800. [CrossRef]

117. Cong, S.; Liu, K.; Qiao, F.; Song, Y.; Tan, M. Biocompatible fluorescent carbon dots derived from roast duck for in vitro cellular and in vivo C. elegans bio-imaging. Methods 2019, 168, 76-83. [CrossRef]

118. Angamuthu, R.; Rajendran, R.; Vairamuthu, R. Quick Microwave Assisted Synthesis and In Vitro Imaging Application of Oxygen Doped Fluorescent Carbon Dots. J. Fluoresc. 2018, 28, 959-966. [CrossRef]

119. Li, C.-L.; Ou, C.-M.; Huang, C.-C.; Wu, W.-C.; Chen, Y.-P.; Lin, T.-E.; Ho, L.-C.; Wang, C.-W.; Shih, C.-C.; Zhou, H.-C.; et al. Carbon dots prepared from ginger exhibiting efficient inhibition of human hepatocellular carcinoma cells. J. Mater. Chem. B 2014, 2, 4564-4571. [CrossRef]

120. Lin, C.; Sun, K.; Zhang, C.; Tan, T.; Xu, M.; Liu, Y.; Xu, C.; Wang, Y.; Li, L.; Whittaker, A.K.; et al. Carbon dots embedded metal organic framework @ chitosan core-shell nanoparticles for vitro dual mode imaging and pH-responsive drug delivery. Microporous Mesoporous Mater. 2020, 293, 109775. [CrossRef]

121. Chong, Y.; Ma, Y.; Shen, H.; Tu, X.; Zhou, X.; Xu, J.; Dai, J.; Fan, S.; Zhang, Z. The in vitro and in vivo toxicity of graphene quantum dots. Biomaterials 2014, 35, 5041-5048. [CrossRef]

122. Cao, L.; Wang, X.; Meziani, M.J.; Lu, F.; Wang, H.; Luo, P.G.; Lin, Y.; Harruff, B.A.; Veca, L.M.; Murray, D.; et al. Carbon Dots for Multiphoton Bioimaging. J. Am. Chem. Soc. 2007, 129, 11318-11319. [CrossRef] [PubMed]

123. Zhi, B.; Yao, X.; Cui, Y.; Orr, G.; Haynes, C.L. Synthesis, applications and potential photoluminescence mechanism of spectrally tunable carbon dots. Nanoscale 2019, 11, 20411-20428. [CrossRef] [PubMed]

124. Sharker, S.M.; Kang, E.B.; Shin, C.; Kim, S.H.; Lee, G.; Park, S.Y. Near-infrared-active and pH-responsive fluorescent polymer-integrated hybrid graphene oxide nanoparticles for the detection and treatment of cancer. J. Appl. Polym. Sci. 2016, 133. [CrossRef]

125. Kim, S.H.; Lee, J.E.; Sharker, S.M.; Jeong, J.H.; In, I.; Park, S.Y. In Vitro and In Vivo Tumor Targeted Photothermal Cancer Therapy Using Functionalized Graphene Nanoparticles. Biomacromolecules 2015, 16, 3519-3529. [CrossRef] [PubMed]

126. Zhang, L.; Lin, Z.; Yu, Y.-X.; Jiang, B.-P.; Shen, X.-C. Multifunctional hyaluronic acid-derived carbon dots for self-targeted imaging-guided photodynamic therapy. J. Mater. Chem. B 2018, 6, 6534-6543. [CrossRef]

127. Prianka, T.R.; Subhan, N.; Reza, H.M.; Hosain, K.; Rahman, A.; Lee, H.; Sharker, S.M. Recent exploration of bio-mimetic nanomaterial for potential biomedical applications. Mater. Sci. Eng. C 2018, 93, 1104-1115. [CrossRef]

128. Tasnim, K.N.; Adrita, S.H.; Hossain, S.; Akash, S.Z.; Sharker, S. The Prospect of Stem Cells for HIV and Cancer Treatment: A Review. Pharm. Biomed. Res. 2020, 6. [CrossRef]

129. Cheng, L.; Wang, C.; Ma, X.; Wang, Q.; Cheng, Y.; Wang, Y.S.H.; Li, Y.; Liu, Z. Multifunctional Upconversion Nanoparticles for Dual-Modal Imaging-Guided Stem Cell Therapy under Remote Magnetic Control. Adv. Funct. Mater. 2012, 23, 272-280. [CrossRef]

130. Lan, M.; Guo, L.; Zhao, S.; Zhang, Z.; Jia, Q.; Yan, L.; Xia, J.; Zhang, H.; Wang, P.; Zhang, W. Carbon Dots as Multifunctional Phototheranostic Agents for Photoacoustic/Fluorescence Imaging and Photothermal/Photodynamic Synergistic Cancer Therapy. Adv. Ther. 2018, 1, 1800077. [CrossRef]

131. Cai, W.; Chen, X. Nanoplatforms for Targeted Molecular Imaging in Living Subjects. Small 2007, 3, $1840-1854$. [CrossRef]

132. Jin, M.; Hao, G.; Sun, X.; Chen, W. Nanoparticle-Based Positron Emission Tomography and Single Photon Emission Computed Tomography Imaging of Cancer. Rev. Nanosci. Nanotechnol. 2012, 1, 3-21. [CrossRef]

133. Shi, X.; Meng, H.; Sun, Y.; Qu, L.; Lin, Y.; Li, Z.; Du, D. Far-Red to Near-Infrared Carbon Dots: Preparation and Applications in Biotechnology. Small 2019, 15, e1901507. [CrossRef] [PubMed]

134. Kim, K.Y. Nanotechnology platforms and physiological challenges for cancer therapeutics. Nanomed. Nanotechnol. Biol. Med. 2007, 3, 103-110. [CrossRef] [PubMed] 
135. Jia, Q.; Zhao, Z.; Liang, K.; Nan, F.; Li, Y.; Wang, J.; Ge, J.; Wang, P. Recent advances and prospects of carbon dots in cancer nanotheranostics. Mater. Chem. Front. 2020, 4, 449-471. [CrossRef]

136. Wang, J.; Xu, M.; Wang, D.; Li, Z.; Primo, F.L.; Tedesco, A.C.; Bi, H. Copper-Doped Carbon Dots for Optical Bioimaging and Photodynamic Therapy. Inorg. Chem. 2019, 58, 13394-13402. [CrossRef]

137. Zhou, Z.; Song, J.; Nie, L.; Chen, X. Reactive oxygen species generating systems meeting challenges of photodynamic cancer therapy. Chem. Soc. Rev. 2016, 45, 6597-6626. [CrossRef]

138. Chen, J.; Fan, T.; Xie, Z.; Zeng, Q.; Xue, P.; Zheng, T.; Chen, Y.; Luo, X.; Zhang, H. Advances in nanomaterials for photodynamic therapy applications: Status and challenges. Biomaterials 2020, 237, 119827. [CrossRef]

139. Yang, W.; Wei, B.; Yangab, Z.; Sheng, L.-Q. Facile synthesis of novel carbon-dots/hemin nanoplatforms for synergistic photo-thermal and photo-dynamic therapies. J. Inorg. Biochem. 2019, 193, 166-172. [CrossRef]

140. Yue, L.; Li, H.; Sun, Q.; Zhang, J.; Luo, X.; Wu, F.; Zhu, X. Red-Emissive Ruthenium-Containing Carbon Dots for Bioimaging and Photodynamic Cancer Therapy. ACS Appl. Nano Mater. 2020, 3, 869-876. [CrossRef]

141. Jia, Q.; Zheng, X.; Ge, J.; Liu, W.; Ren, H.; Chen, S.; Wen, Y.; Zhang, H.; Wu, J.; Zhang, W. Synthesis of carbon dots from Hypocrella bambusae for bimodel fluorescence/photoacoustic imaging-guided synergistic photodynamic/photothermal therapy of cancer. J. Colloid Interface Sci. 2018, 526, 302-311. [CrossRef]

142. Huang, P.; Lin, J.; Wang, X.; Wang, Z.; Zhang, C.; He, M.; Wang, K.; Chen, F.; Li, Z.; Shen, G.; et al. Light-Triggered Theranostics Based on Photosensitizer-Conjugated Carbon Dots for Simultaneous Enhanced-Fluorescence Imaging and Photodynamic Therapy. Adv. Mater. 2012, 24, 5104-5110. [CrossRef] [PubMed]

143. Afonso, D.; Valetti, S.; Fraix, A.; Bascetta, C.; Petralia, S.; Conoci, S.; Feiler, A.; Sortino, S. Multivalent mesoporous silica nanoparticles photo-delivering nitric oxide with carbon dots as fluorescence reporters. Nanoscale 2017, 9, 13404-13408. [CrossRef] [PubMed]

144. Park, S.J.; Kang, E.B.; Sharker, S.M.; Lee, G.; In, I.; Park, S.Y. NIR-Mediated Antibacterial Clay Nanocomposites: Exfoliation of Montmorillonite Nanolayers by IR825 Intercalation. Macromol. Mater. Eng. 2015, 301, 141-148. [CrossRef]

145. Jeong, C.J.; Sharker, S.M.; In, I.; Park, S.Y. Iron Oxide@PEDOT-Based Recyclable Photothermal Nanoparticles with Poly(vinylpyrrolidone) Sulfobetaines for Rapid and Effective Antibacterial Activity. ACS Appl. Mater. Interfaces 2015, 7, 9469-9478. [CrossRef] [PubMed]

146. Yoon, H.Y.; Koo, H.; Choi, K.Y.; Lee, S.J.; Kim, K.; Kwon, I.C.; Leary, J.F.; Park, K.; Yuk, S.H.; Park, J.H.; et al. Tumor-targeting hyaluronic acid nanoparticles for photodynamic imaging and therapy. Biomaterials 2012, 33, 3980-3989. [CrossRef]

147. Sun, S.; Chen, J.; Jiang, K.; Tang, Z.; Wang, Y.; Li, Z.; Liu, C.; Wu, A.; Lin, H. Ce6-Modified Carbon Dots for Multimodal-Imaging-Guided and Single-NIR-Laser-Triggered Photothermal/Photodynamic Synergistic Cancer Therapy by Reduced Irradiation Power. ACS Appl. Mater. Interfaces 2019, 11, 5791-5803. [CrossRef]

148. Hakim, L.; Nahar, N.; Saha, M.; Islam, M.S.; Reza, H.M.; Sharker, S.M. Local drug delivery from surgical thread for area-specific anesthesia. Biomed. Phys. Eng. Express 2020, 6, 015028. [CrossRef]

149. Mohammadinejad, R.; Dadashzadeh, A.; Moghassemi, S.; Ashrafizadeh, M.; Dehshahri, A.; Sohrevardi, S.-M.; Sassan, H.; Sohrevardi, S.-M.; Mandegary, A. Shedding light on gene therapy: Carbon dots for the minimally invasive image-guided delivery of plasmids and noncoding RNAs-A review. J. Adv. Res. 2019, 18, 81-93. [CrossRef]

150. Del Rosal, B.; Jaque, D. Upconversion nanoparticles for in vivo applications: Limitations and future perspectives. Methods Appl. Fluoresc. 2019, 7, 022001. [CrossRef]

151. Wang, Y.; Guo, G.; Gao, J.; Li, Z.; Yin, X.; Zhu, C.; Xia, Y. Multicenter-Emitting Carbon Dots: Color Tunable Fluorescence and Dynamics Monitoring Oxidative Stress In Vivo. Chem. Mater. 2020, 32. [CrossRef]

152. Lane, M.E. Nanoparticles and the skin-Applications and limitations. J. Microencapsul. 2011, 28, 709-716. [CrossRef] [PubMed]

153. Li, S.; Guo, Z.; Zhang, Y.; Xue, W.; Liu, Z. Blood Compatibility Evaluations of Fluorescent Carbon Dots. ACS Appl. Mater. Interfaces 2015, 7, 19153-19162. [CrossRef]

154. Su, W.; Wu, H.; Xu, H.; Zhang, Y.; Li, Y.; Li, X.; Fan, L. Carbon dots: A booming material for biomedical applications. Mater. Chem. Front. 2020, 4, 821-836. [CrossRef]

155. Li, H.; Xu, Y.; Kong, D.; Jin, R.; Sun, C.; Du, D.; Lin, Y.; Lu, G. Recent advances in carbon dots for bioimaging applications. Nanoscale Horiz. 2020, 5, 218-234. [CrossRef] 
156. Yuan, Y.; Guo, B.; Hao, L.; Liu, N.; Lin, Y.; Guo, W.; Li, X. Doxorubicin-loaded environmentally friendly carbon dots as a novel drug delivery system for nucleus targeted cancer therapy. Colloids Surf. B Biointerfaces 2017, 159, 349-359. [CrossRef] [PubMed]

157. Wang, J.; Liu, G.; Leung, K.; Loffroy, R.; Lu, P.-X.; Wang, Y.-X.J. Opportunities and Challenges of Fluorescent Carbon Dots in Translational Optical Imaging. Curr. Pharm. Des. 2015, 21, 5401-5416. [CrossRef]

158. Shamsipur, M.; Barati, A.; Karami, S. Long-wavelength, multicolor, and white-light emitting carbon-based dots: Achievements made, challenges remaining, and applications. Carbon 2017, 124, 429-472. [CrossRef]

159. Pirsaheb, M.; Mohammadi, S.; Salimi, A.; Payandeh, M. Functionalized fluorescent carbon nanostructures for targeted imaging of cancer cells: A review. Microchim. Acta 2019, 186, 231. [CrossRef]

160. Zhang, P.; Hu, C.; Ran, W.; Meng, J.; Yin, Q.; Li, Y. Recent Progress in Light-Triggered Nanotheranostics for Cancer Treatment. Theranostics 2016, 6, 948-968. [CrossRef]

161. Zheng, M.; Li, Y.; Liu, S.; Wang, L.; Xie, Z.; Jing, X. One-Pot To Synthesize Multifunctional Carbon Dots for Near Infrared Fluorescence Imaging and Photothermal Cancer Therapy. ACS Appl. Mater. Interfaces 2016, 8 , 23533-23541. [CrossRef]

162. Peng, F.; Su, Y.; Zhong, Y.; Fan, C.; Lee, S.-T.; He, Y. Silicon Nanomaterials Platform for Bioimaging, Biosensing, and Cancer Therapy. Acc. Chem. Res. 2014, 47, 612-623. [CrossRef] [PubMed]

163. Atabaev, T.S. Doped Carbon Dots for Sensing and Bioimaging Applications: A Minireview. Nanomaterials 2018, 8, 342. [CrossRef]

164. Wu, Y.-F.; Wu, H.-C.; Kuan, C.-H.; Lin, C.-J.; Wang, L.-W.; Chang, C.-W.; Wang, T.-W. Multi-functionalized carbon dots as theranostic nanoagent for gene delivery in lung cancer therapy. Sci. Rep. 2016, 6, 21170. [CrossRef] [PubMed]

165. Saleem, J.; Wang, L.; Chen, C. Carbon-Based Nanomaterials for Cancer Therapy via Targeting Tumor Microenvironment. Adv. Healthc. Mater. 2018, 7, e1800525. [CrossRef]

166. Gulino, A.; Miele, E.; Spinelli, G.P.; Miele, E.; Di Fabrizio, E.; Ferretti, E.; Tomao, S. Nanoparticle-based delivery of small interfering RNA: Challenges for cancer therapy. Int. J. Nanomed. 2012, 7, 3637-3657. [CrossRef] [PubMed]

167. Xu, N.; Du, J.; Yao, Q.; Ge, H.; Li, H.; Xu, F.; Gao, F.; Xian, L.; Fan, J.; Peng, X. Precise photodynamic therapy: Penetrating the nuclear envelope with photosensitive carbon dots. Carbon 2020, 159, 74-82. [CrossRef]

168. Navya, P.N.; Kaphle, A.; Srinivas, S.P.; Bhargava, S.K.; Rotello, V.M.; Daima, H.K. Current trends and challenges in cancer management and therapy using designer nanomaterials. Nano Converg. 2019, 6, 1-30. [CrossRef]

169. Ashrafizadeh, M.; Mohammadinejad, R.; Kailasa, S.K.; Ahmadi, Z.; Afshar, E.G.; Pardakhty, A. Carbon dots as versatile nanoarchitectures for the treatment of neurological disorders and their theranostic applications: A review. Adv. Colloid Interface Sci. 2020, 278, 102123. [CrossRef]

170. He, X.; Gao, J.; Gambhir, S.S.; Cheng, Z. Near-infrared fluorescent nanoprobes for cancer molecular imaging: Status and challenges. Trends Mol. Med. 2010, 16, 574-583. [CrossRef]

171. Feng, L.; Liu, Z. Graphene in biomedicine: Opportunities and challenges. Nanomedicine 2011, 6, 317-324. [CrossRef]

172. Zhang, L.; Zheng, W.; Tang, R.; Wang, N.; Zhang, W.; Jiang, X. Gene regulation with carbon-based siRNA conjugates for cancer therapy. Biomaterials 2016, 104, 269-278. [CrossRef] [PubMed]

173. Dong, X.; Liang, W.; Meziani, M.J.; Sun, Y.-P.; Yang, L. Carbon Dots as Potent Antimicrobial Agents. Theranostics 2020, 10, 671-686. [CrossRef] [PubMed]

174. Li, S.; Peng, Z.; Dallman, J.; Baker, J.; Othman, A.M.; Blackwelder, P.L.; Leblanc, R.M. Crossing the blood-brain-barrier with transferrin conjugated carbon dots: A zebrafish model study. Colloids Surf. B Biointerfaces 2016, 145, 251-256. [CrossRef] [PubMed]

175. Orecchioni, M.; Cabizza, R.; Bianco, A.; Delogu, L.G. Graphene as Cancer Theranostic Tool: Progress and Future Challenges. Theranostics 2015, 5, 710-723. [CrossRef]

176. Zhao, X.; Gao, W.; Zhang, H.; Qiu, X.; Luo, Y. Graphene quantum dots in biomedical applications: Recent advances and future challenges. In Handbook of Nanomaterials in Analytical Chemistry; Elsevier: Amsterdam, The Netherlands, 2020; pp. 493-505.

177. Zhao, H.; Duan, J.; Xiao, Y.; Tang, G.; Wu, C.; Zhang, Y.; Liu, Z.; Xue, W. Microenvironment-Driven Cascaded Responsive Hybrid Carbon Dots as a Multifunctional Theranostic Nanoplatform for Imaging-Traceable Gene Precise Delivery. Chem. Mater. 2018, 30, 3438-3453. [CrossRef] 
178. Singh, A.; Trivedi, P.; Jain, N.K. Advances in siRNA delivery in cancer therapy. Artif. Cells Nanomed. Biotechnol. 2018, 46, 274-283. [CrossRef]

179. Sun, S.; Zhang, L.; Jiang, K.; Wu, A.; Lin, H. Toward High-Efficient Red Emissive Carbon Dots: Facile Preparation, Unique Properties, and Applications as Multifunctional Theranostic Agents. Chem. Mater. 2016, 28, 8659-8668. [CrossRef]

180. Ghosal, K.; Ghosh, A. Carbon dots: The next generation platform for biomedical applications. Mater. Sci. Eng. C 2019, 96, 887-903. [CrossRef]

181. Krishnan, S.; Diagaradjane, P.; Cho, S.H. Nanoparticle-mediated thermal therapy: Evolving strategies for prostate cancer therapy. Int. J. Hyperth. 2010, 26, 775-789. [CrossRef]

182. Bor, G.; Azmi, I.D.M.; Yaghmur, A. Nanomedicines for cancer therapy: Current status, challenges and future prospects. Ther. Deliv. 2019, 10, 113-132. [CrossRef]

183. Pardo, J.; Peng, Z.; Leblanc, R.M. Cancer Targeting and Drug Delivery Using Carbon-Based Quantum Dots and Nanotubes. Molecules 2018, 23, 378. [CrossRef] [PubMed]

184. Kim, S.; Choi, Y.; Park, G.; Won, C.; Park, Y.-J.; Lee, Y.; Kim, B.; Min, D.-H. Highly efficient gene silencing and bioimaging based on fluorescent carbon dots in vitro and in vivo. Nano Res. 2016, 10, 503-519. [CrossRef]

185. Rahmati, M.; Mozafari, M. Nano-immunoengineering: Opportunities and challenges. Curr. Opin. Biomed. Eng. 2019, 10, 51-59. [CrossRef]

186. Bottini, M.; Sacchetti, C.; Pietroiusti, A.; Bellucci, S.; Magrini, A.; Rosato, N.; Bottini, N. Targeted Nanodrugs for Cancer Therapy: Prospects and Challenges. J. Nanosci. Nanotechnol. 2014, 14, 98-114. [CrossRef] [PubMed]

187. Sun, X.; Lei, Y. Fluorescent carbon dots and their sensing applications. TrAC Trends Anal. Chem. 2017, 89, 163-180. [CrossRef]

188. Kashyap, D.; Tuli, H.S.; Yerer, M.B.; Sharma, A.; Sak, K.; Srivastava, S.; Pandey, A.; Garg, V.K.; Sethi, G.; Bishayee, A. Natural product-based nanoformulations for cancer therapy: Opportunities and challenges. Semin. Cancer Biol. 2019, in press. [CrossRef]

189. Tripodo, G.; Trapani, A.; Torre, M.L.; Giammona, G.; Trapani, G.; Mandracchia, D. Hyaluronic acid and its derivatives in drug delivery and imaging: Recent advances and challenges. Eur. J. Pharm. Biopharm. 2015, 97, 400-416. [CrossRef]

190. Huo, F.; Karmaker, P.G.; Liu, Y.; Zhao, B.; Yang, X.-P. Preparation and Biomedical Applications of Multicolor Carbon Dots: Recent Advances and Future Challenges. Part. Part. Syst. Charact. 2020, 37, 1900489. [CrossRef]

191. Scheinberg, D.A.; Villa, C.H.; Escorcia, F.E.; McDevitt, M.R. Conscripts of the infinite armada: Systemic cancer therapy using nanomaterials. Nat. Rev. Clin. Oncol. 2010, 7, 266-276. [CrossRef]

192. Bayda, S.; Hadla, M.; Palazzolo, S.; Riello, P.; Corona, G.; Toffoli, G.; Rizzolio, F. Inorganic Nanoparticles for Cancer Therapy: A Transition from Lab to Clinic. Curr. Med. Chem. 2018, 25, 4269-4303. [CrossRef]

193. Yao, B.; Huang, H.; Liu, Y.; Kang, Z. Carbon Dots: A Small Conundrum. Trends Chem. 2019, 1, $235-246$. [CrossRef]

194. Sharma, A.; Das, J. Small molecules derived carbon dots: Synthesis and applications in sensing, catalysis, imaging, and biomedicine. J. Nanobiotechnol. 2019, 17, 92. [CrossRef] [PubMed]

Publisher's Note: MDPI stays neutral with regard to jurisdictional claims in published maps and institutional affiliations.

(C) 2020 by the authors. Licensee MDPI, Basel, Switzerland. This article is an open access article distributed under the terms and conditions of the Creative Commons Attribution (CC BY) license (http://creativecommons.org/licenses/by/4.0/). 